Review

\title{
A Review of Glutamate Receptors I: Current Understanding of Their Biology
}

\author{
Colin G. Rousseaux ${ }^{1}$ \\ ${ }^{1}$ Department of Pathology and Laboratory Medicine, Faculty of Medicine, University of Ottawa, Ottawa, Ontario, Canada
}

\begin{abstract}
Seventy years ago it was discovered that glutamate is abundant in the brain and that it plays a central role in brain metabolism. However, it took the scientific community a long time to realize that glutamate also acts as a neurotransmitter. Glutamate is an amino acid and brain tissue contains as much as $5-15 \mathrm{mM}$ glutamate per $\mathrm{kg}$ depending on the region, which is more than of any other amino acid. The main motivation for the ongoing research on glutamate is due to the role of glutamate in the signal transduction in the nervous systems of apparently all complex living organisms, including man. Glutamate is considered to be the major mediator of excitatory signals in the mammalian central nervous system and is involved in most aspects of normal brain function including cognition, memory and learning. In this review, the basic biology of the excitatory amino acids glutamate, glutamate receptors, GABA, and glycine will first be explored. In the second part of this review, the known pathophysiology and pathology will be described. (J Toxicol Pathol 2008; 21: 25-51)
\end{abstract}

Key words: glutamate, glycine, GABA, glutamate receptors, ionotropic, metabotropic, NMDA, AMPA, review

\section{Introduction and Overview}

In the first decades of the 20th century, research into the chemical mediation of the "autonomous" (autonomic) nervous system (ANS) was an area that received much research activity. In England, William Maddock Bayliss, Ernest Henry Starling, Henry Dale and T.R. Elliot were investigating the actions and properties of this system following the recent identification of acetylcholine and adrenaline. In Vienna, Austria, Otto Loewi provided the first reliable evidence for the existence of chemical transmission by acetylcholine in 1921, then other chemical mediators between 1929 and 1936 . Loewi doubted that neurotransmitters operated in the voluntary nervous system, but the discovery that acetylcholine is also a neurotransmitter in the neuromotor synapse, and that preganglionic synapses in the ANS are all cholinergic, in contrast with the postganglionic cholinergic or adrenergic receptors, proved him incorrect. Later it was found that the transmitter acting in adrenergic synapses was not adrenalin (epinephrine) but noradrenalin (norepinephrine) ${ }^{1}$. We now recognize three major categories of substances that act as neurotransmitters. These are amino acids (primarily glutamic acid, $\gamma$-amino butyric acid, aspartic acid and

Received: 10 October 2007, Accepted: 14 November 2007 Mailing address: Colin G. Rousseaux, 19 Klondike Rd., Wakefield, QC, J0X 3G0, Canada

TEL: 1 (819) 459-2998 FAX: 1 (819) 459-2960

E-mail: crousseaux@crxassociates.com glycine), peptides (vasopressin, somatostatin, neurotensin, etc.), and monoamines (norepinephrine, dopamine and serotonin) plus acetylcholine.

Glutamatergic synaptic transmission in the mammalian central nervous system (CNS) was slowly established over a period of some 20 years, dating from the $1950 \mathrm{~s}^{2-4}$. Realization that glutamate and similar excitatory amino acids (EAAs), such as domoic acid, mediated their excitatory actions via multiple receptors preceded establishment of these receptors as synaptic transmitter receptors ${ }^{5}$. EAA receptors were initially classified as N-methyl-D-aspartate (NMDA) and non-NMDA receptors.

Non-NMDA glutamate receptors were subdivided into $\alpha$-amino-3-hydroxy-5-methylisoxazole-4- propionic acid (also known as AMPA receptor, AMPAR, or quisqualate receptor) and kainate $(\mathrm{Ka})$ receptors following experiments with agonists that appeared to activate these receptors preferentially. In addition, their sensitivity to a range of differentially acting antagonists was understood during the 1970s. NMDA receptors were definitively shown to be synaptic receptors on spinal neurons by the sensitivity of certain excitatory pathways in the spinal cord to a range of specific NMDA receptor antagonists. However, specific NMDA receptor antagonists appeared to be less effective at synapses in higher centers. In contrast, antagonists that also blocked non-NMDA as well as NMDA receptors were almost universally effective at blocking synaptic excitation within the brain and spinal cord, establishing both the existence and ubiquity of non-NMDA synaptic receptor systems throughout the $\mathrm{CNS}^{6}$. 
In the early $1980 \mathrm{~s}, \mathrm{NMDA}$ receptors were shown to be involved in several central synaptic pathways, acting in concert with non-NMDA receptors under conditions where a protracted excitatory postsynaptic potential was seen in response to intense stimulation of presynaptic fibers. Such activation of NMDA receptors together with non-NMDA receptors led to the phenomenon of long-term potentiation $(\mathrm{LTP})^{7}$. LTP is associated with lasting changes in synaptic efficacy (synaptic plasticity) and has been considered to be an important process in memory ${ }^{8}$ and learning 9 .

During the same period, it was shown that certain glutamate receptors (GluRs) in the brain mediated biochemical changes that were not susceptible to NMDA or non-NMDA receptor antagonists. This dichotomy was resolved in the early 1990s using molecular biology, which identified two families of glutamate binding receptor proteins: ionotropic (iGluR) and metabotropic (mGluR) glutamate receptors ${ }^{10}$. Development of antagonists binding to specific protein subunits is currently enabling precise identification of discrete iGluR or mGluR subtypes ${ }^{11}$ that participate in a range of central synaptic processes, including synaptic plasticity ${ }^{12-14}$.

It is the purpose of this review to summarize the biological activities of the glutamate system (Part I) and to relate changes in these receptors to normal physiology and disease entities (Part II). Efforts have been made to address the toxicologic pathology of these receptors wherever possible; however, although the literature has a number of examples of receptor visualization by immunohistochemistry, the role of these receptors in abnormal morphology is still under intense investigation.

\section{The Glutamate System}

A number of authors have discussed the importance of the glutamate system, e.g., ${ }^{15-18}$, and its regulation ${ }^{19,20}$. The following discussion not only addresses, glutamate, GABA, and glycine but also details how excitatory amino acids may interact with the glutamate system.

\section{Excitatory amino acids (EAAs)}

Glutamate (Glu) and aspartate (Asp) are amino acids (AAs) that act as major excitatory neurotransmitters in the mammalian central nervous system ${ }^{21-25}$ by stimulating or exciting postsynaptic neurons. Although these AAs are primarily involved in intermediary metabolism and other non-neuronal functions, their most important role is as neurotransmitters. It is estimated Glu mediates nearly $50 \%$ of all the synaptic transmissions in the CNS and its involvement is implicated in nearly all aspects of normal brain function including learning, memory, movement, cognition and development ${ }^{21,26-34}$.

These EAAs and their various analogues can be neurotoxic, particularly when they excessively stimulate the same excitatory receptors, which is a phenomenon known as excitotoxicity $21,22,24,25,35,36$. At elevated concentrations, Glu acts as a neurotoxin capable of inducing severe neuronal damage and necrosis by causing over excitation of neurons ${ }^{37-41}$. Previously it was thought that hypoxia played a part in the neurotoxicity of Glu, particularly in the white matter; however, it has now been shown that hypoxic injury and GluRs over stimulation are independent of one another ${ }^{42}$.

EAAs access the brain tissue of the circumventricular organs located outside the blood brain barrier $(\mathrm{BBB})^{43-45}$. Despite the BBB protective mechanisms, the local or circulating concentrations of these excitatory compounds may be great enough to induce damage leading to neurotoxic exposure levels. The toxicity of each EAA compound varies according to the potency, the chemical availability, the rate of absorption, the affinity to specific receptors and the particular anatomical target site ${ }^{46-48}$. In addition, the susceptibility, genetic predisposition and health status of the individual are also important factors.

\section{Excitotoxicity}

The neurotoxic effects of the EAAs are dependent on the species, developmental stage of the animal, type of agonist, duration of exposure to the agonist and the cellular expression of the GluR subtypes. Regardless, neurons under various conditions can become so over stimulated by Glu that it actually kills them through receptor-mediated depolarization and calcium $\left(\mathrm{Ca}^{++}\right)$influx ${ }^{49,50}$. There are five main factors necessary for the transition of Glu and Asp from neurotransmitters to excitotoxins. These include inadequate neuronal ATP levels, inadequate neuronal levels of magnesium $\left(\mathrm{Mg}^{++}\right)$; high concentrations of inflammatory prostaglandins; excessive free radical formation ${ }^{51,52}$, and inadequate removal of synaptic Glu ${ }^{53,54}$.

An array of GluRs is known to be present on pre- and post-synaptic membranes that are used to transduce integrated signals using an increased ion flux and second messenger pathways ${ }^{21,24,25,33,34,55-57}$. It is the excessive activation of these receptors that leads to neurotoxicity, often referred to as "excitotoxicity" 58 . In addition, it has been postulated that excitotoxicity is involved in the pathogenesis of many types of acute and chronic insults to the $\mathrm{CNS}^{59}$ and peripheral tissues ${ }^{60,61}$.

The AAs, Glu and Asp, including structurally similar compounds, can be dietary excitotoxins ${ }^{62}$. Domoic acid (DA) is one of the most potent neurotoxins in seafood that can enter our food supply ${ }^{63}$. Contamination of mussels by the sea diatoms producing DA was found to be the reason for the outbreak of the lethal shellfish poisoning that occurred in Canada in 198765-67. The clinical manifestations of DA intoxication are related to its effect in the brain including severe seizures ${ }^{63-71}$ and survivors of severe cases suffered permanent loss of short-term memory, a phenomenon that lead to the term amnesic shellfish poisoning ${ }^{66}$. However, the other clinical symptoms such as gastrointestinal disturbances, cardiovascular collapse and cardiac arrhythmia ${ }^{43,63,70,72}$ have also been noted, and could be related to the DA poisoning ${ }^{60}$. Recently, DA poisoning in California Sea Lions has been reported ${ }^{73}$. 
Disturbance of Glu homeostasis probably plays a pivotal role in the execution of pathological changes in many disease states involving the tissues listed above. There may be a number of factors that trigger the neurotoxic potential of endogenous Glu including increase in Glu release, malfunctioning of neuronal and glial uptake, energy deficits, neuronal depolarization, changes in GluR properties or expression patterns, free radical formation and others ${ }^{49,50,74-}$ 77. Excitotoxicity has also been suggested as a central mechanism in fluoride neurotoxicity ${ }^{78,79}$.

Such excitotoxic effects can be pronounced during acute events such as ischemic stroke and trauma, or milder but prolonged in chronic neurodegenerative diseases such as Alzheimer's disease, Parkinson's disease, Huntington's disease and amyotrophic lateral sclerosis ${ }^{76,80-82}$. As will be discussed in the second article of this series, glutamatergic dysfunction is also involved in the symptomatology of disorders such schizophrenia, anxiety, and depression ${ }^{50,74}$. In addition, glutamatergic dysfunction has been regarded as part of the development of disorders associated with longterm plastic changes in the CNS such as chronic pain, drug tolerance, dependence, addiction, partial complex seizures and tardive dyskinesia ${ }^{50,74,83,84}$.

It has been suggested that monosodium glutamate (MSG) is toxic and can exert its toxicity via similar mechanisms to L-glutamate (L-Glu). Administration of MSG during the neonatal period produces marked cognitive effects due to the loss of synaptic plasticity in rodents ${ }^{85}$; however, the effect of MSG on long-term brain function in humans has been questioned ${ }^{86}$. The route of administration can explain the differences in these findings, where human exposure is much lower occurring via the oral route.

\section{Glutamate, gamma aminobutyric acid, and glycine}

Historically, AAs (including Glu and Asp) were studied in the context of their importance in protein synthesis, but in the 1950s the focus of research shifted as AAs became recognized as putative neurotransmitters. For compounds to be classified as neurotransmitters they show several characteristics in common ${ }^{87,88}$. These characteristics are: the neurotransmitter is synthesized, stored, and released from the presynaptic terminal; specific neurotransmitter receptors are localized on the postsynaptic cells; and there exists a mechanism to stop neurotransmitter release and clear molecules from the cleft. Glu was found to fulfill the requirements above and thus was named a neurotransmitter ${ }^{89}$.

Although many AAs play a role in neurotransmission, Glu, glycine (Gly), and $\gamma$-aminobutyric acid (GABA) are among the more common and better-understood neurotransmitters ${ }^{74,90,91}$. They are all metabolic intermediates and neurotransmitters, where Glu is the major excitatory neurotransmitter, and Gly and GABA are the major inhibitory neurotransmitters, in the $\mathrm{CNS}^{92}$. Glu, which is synthesized, stored, and released from the presynaptic terminal, has specific neurotransmitter receptors localized on the postsynaptic cells, and is eliminated from

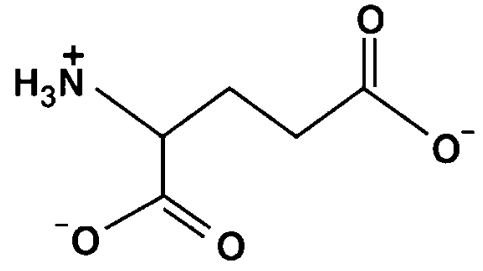

Fig. 1. The structure of glutamic acid

Table 1. Biological Functions of Glutamate

\begin{tabular}{l} 
Functions of glutamate \\
\hline 1. Substrate for protein synthesis \\
2. Precursor of glutamine \\
3. N transport (muscle-glutamine; brain) \\
4. Neurotransmitter (and $\gamma$-aminobutyrate) \\
5. Polyglutamate and cell signaling \\
6. D-Carboxylation of glutamate \\
7. Substrate for glutathione production \\
8. Precursor of N-acetylglutamate \\
9. Active sites of enzymes \\
10. Inhibitor of glutaminase reaction \\
11. Citric acid cycle intermediate \\
12. Energy source for some tissues (mucosa)
\end{tabular}

Alpha-ketoglutarate

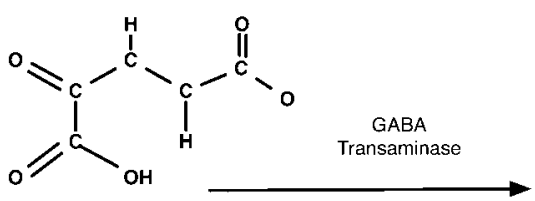<smiles>NC(C=O)C(=O)O</smiles>

Glutamate
Fig. 2. The synthesis of glutamate

the synaptic cleft by specific transporters: it is a neurotransmitter.

L-Glu acts through both ligand-gated ion channels at ionotropic receptors (iGluR) and at G-protein coupled metabotropic receptors (mGluR). As will be discussed in more detail later, activation of these receptors is responsible for basal excitatory synaptic transmission and many forms of synaptic plasticity such as long-term potentiation (LTP) and long-term depression (LTD), which are thought to underlie learning and memory ${ }^{91}$.

\section{1) Glutamate}

Glu has a number of functions that are listed in Table 1. a) Glutamate synthesis

Glu is enzymatically created from $\alpha$-ketoglutarate via GABA transaminase as is shown in Fig. $2^{93}$.

$\mathrm{N}$-Acetyl-aspartyl-glutamate (NAAG) is abundant in the mammalian CNS, which has led to the hypothesis that this dipeptide is the storage form of Glu. The membrane bound metallopeptidase NAALADase (N-acetyl-a-linkedacidic dipeptidase, or glutamate carboxypeptidase II, E.C. 
3.4.17.21) is co-localized with NAAG in the CNS and converts NAAG to N-Acetyl-aspartate (NAA) and $\mathrm{Glu}^{94}$. It seems likely that NAAG is also a weak partial agonist at Nmethyl-D-aspartic acid (NMDA) ${ }^{95}$. This effect is seen at concentrations beyond therapeutically relevant levels. Inhibition of NAALADase could be useful in numerous CNS disorders associated with disturbances in glutamatergic transmission by decreasing the concentration of Glu and increasing the concentration of NAAG ${ }^{96}$.

b) Glutamate uptake

Brain tissue has a remarkable ability to accumulate Glu, an ability resulting from glutamate transporter proteins (GluTP) present in the plasma membranes of both glial cells and neurons ${ }^{97}$. Glu and its structural analogues may enter the food supply during preparation or processing as contaminants or additives in its free form or bound to peptides and proteins ${ }^{64-77,98-101}$. These analogues include monosodium glutamate (MSG), L-aspartate, L-cysteine, related sulfur AAs, B- $N$-oxalyamino-L-alanine (BOAA or ODAP), B- $N$-methyl-amino-L-alanine (BMAA) and the seafood toxin domoic acid (DA) 21,63,64,99-104.

From Glu labeling studies, the average concentration of Glu in ganglion cells is five $\mathrm{mM}^{105}$. Physiological studies using isolated cells indicate that only $\mu \mathrm{M}$ levels of Glu are required to activate GluR ${ }^{106-108}$. Thus, the amount of Glu released into the synaptic cleft is several orders of magnitude higher than the concentration required for activating most postsynaptic receptors.

c) Glutamate metabolism

Two key goals of brain AA handling are to maintain a very low intrasynaptic concentration of glutamic acid and also to provide the system with precursors from which to synthesize Glu. The intrasynaptic Glu level must be kept low to maximize the signal-to-noise ratio upon the release of Glu from nerve terminals, and to minimize the risk of excitotoxicity consequent to excessive glutamatergic stimulation of susceptible neurons. Additionally, the brain must also provide neurons with a constant supply of Glu, which both neurons and glia robustly oxidize. Astrocytes, which are in close approximation to brain capillaries, probably are the initial site of metabolism of Glu. Astrocytes release the cognate ketoacid [ $\alpha$-ketoisocaproate (KIC)] to neurons, which have a cytosolic branched-chain aminotransferase that reaminates the KIC to leucine, in the process consuming Glu and providing a mechanism for the buffering of Glu if concentrations become excessive ${ }^{109}$.

The liver is the major site of gluconeogenesis, the major organ of AA catabolism and the only organ with a complete urea cycle ${ }^{110}$. It has been suggested that these AAs are oxidized in the liver; however, total oxidation cannot occur within the confines of hepatic oxygen uptake and ATP homeostasis. Rather, most AAs are oxidized only partially in the liver, with the bulk of their carbon skeleton being converted to glucose. The nitrogen is converted to urea and, to a lesser extent, to glutamine. The integration of the urea cycle with gluconeogenesis ensures that the bulk of the reducing power (NADH) required in the cytosol for gluconeogenesis can be provided by ancillary reactions of the urea cycle ${ }^{111}$.

Glu is at the center of these metabolic events. It is central because of the well-described transdeamination system involving aminotransferases and Glu dehydrogenase, where Glu plays a key catalytic role in the removal of $\alpha$ amino nitrogen from AAs. In addition, the "glutamate family" of AAs (arginine, ornithine, proline, histidine and glutamine) requires the conversion of these AAs to Glu for their metabolic disposal. Finally, Glu serves as substrate for the synthesis of $\mathrm{N}$-acetylglutamate, an essential allosteric activator of carbamyl phosphate synthetase I, a key regulatory enzyme in the urea cycle ${ }^{112}$.

d) Glutamate clearance

It has been calculated that a $70-\mathrm{kg}$ man has a daily Glu intake of approximately $28 \mathrm{~g}$ that is derived from the diet and from the breakdown of gut proteins. The daily Glu turnover in the body is about $48 \mathrm{~g}$. Glu is eliminated from the synaptic cleft by specific transporters. Despite this large turnover, the total pool of Glu in blood is quite small, approximately $20 \mathrm{mg}$, because of its rapid extraction from and utilization by various tissues, particularly muscle and liver ${ }^{113,114}$. In the CNS, Glu clearance and, as a consequence, Glu concentration and diffusion in the extracellular space, is associated with the degree of astrocytic coverage of its neurons ${ }^{115}$.

e) Glutamate transporters (GluTPs)

Brain tissue has a remarkable ability to accumulate Glu, an ability due to GluTPs present in the plasma membranes of both glial cells and neurons. GluTPs represent the only significant mechanism for removal of Glu from the extracellular fluid and are important for the long-term maintenance of low and non-toxic concentrations of Glu and appear to have more sophisticated functions in the modulation of neurotransmission ${ }^{97}$. They may modify the time course of synaptic events ${ }^{116}$, the extent and pattern of activation and desensitization of receptors outside the synaptic cleft and at neighboring synapses (intersynaptic cross talk).

The genes encoding GluTPs have been cloned both from rats and humans ${ }^{117,118}$. The human transporters EAAT1 and EAAT2 (rat equivalents GLAST and GLT1) are found in astroglia and microglia widely distributed throughout the CNS. The highest concentration can be found in the cortex. Human EAAT3 (rat EAAC1) is thought to be restricted to neurons; however, it also has been found outside of the CNS. More restrictively, human EAAT4 is expressed only by cerebellar neurons. Further investigation into the neuronal vesicular Glu transporter uncovered VGLUT1, which is only expressed in glutamatergic neurons ${ }^{119,120}$.

GluTPs provide Glu for synthesis of GABA, glutathione and protein, which can be used structurally, or for energy production ${ }^{97}$. Glu uptake appears to be modulated molecularly on virtually all possible levels including DNA transcription, mRNA splicing and degradation, protein synthesis and targeting, actual AA transport activity and associated ion channel activities. A number of soluble 


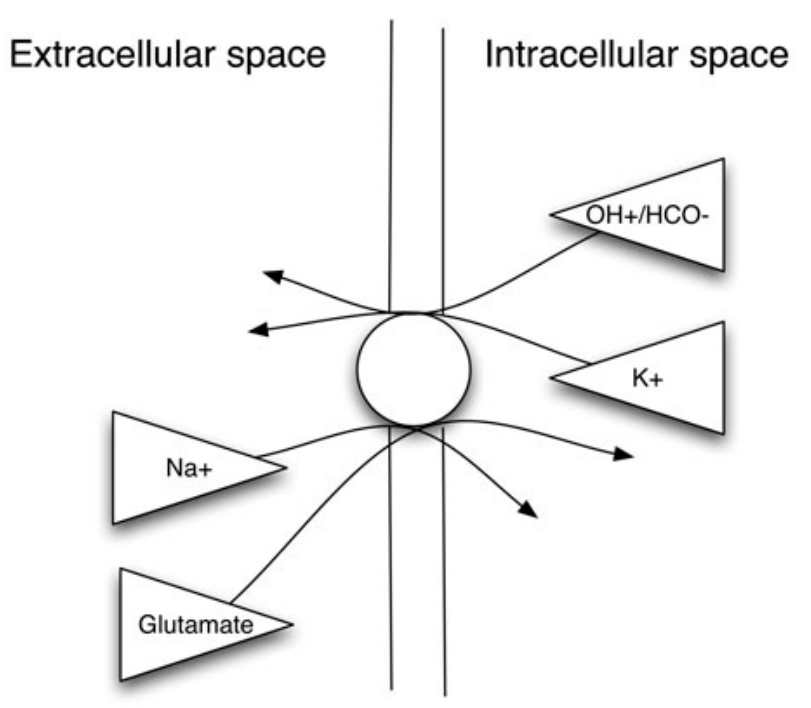

Cell wall

Fig. 3. Diagram showing glutamate transport across the cell wall

compounds, including Glu, cytokines, and growth factors, influence the GluTP expression and activities ${ }^{121}$.

GluTPs have been identified in a number of neural tissues where they assist in maintaining appropriate concentrations of Glu at its synaptic site. Many tissues demonstrate Glu, GluR and GluTPs, including but not limited to, $\mathrm{CNS}^{122}$, autonomic and sensory ganglia ${ }^{123}$, peripheral nerves - myelinated and unmyelinated ${ }^{124,125}$, vagus and other cholinergic nerves ${ }^{124}$, tachykinin containing sensory nerves and vestibular tissues ${ }^{126,127}$ retinal photoreceptors ${ }^{128-130}$, Muller cells ${ }^{128,131}$, adrenal medulla $^{123,133}$, pituitary ${ }^{134}$, pineal gland ${ }^{135}$, endocrine pancreas $^{136-147}$, immune system ${ }^{148}$, taste buds ${ }^{149,150}$, esophagus $^{151}$, gut ${ }^{70,100,152-154}$, ileal longitudinal muscle ${ }^{155-157}$ hepatocytes ${ }^{68,158}$, kidney, spleens, ovaries ${ }^{48,159}$, lungs ${ }^{60,99,145,148,154,158-165}$, heart ${ }^{60,99,145,148,154,158-165}$, bone ${ }^{159,165}$, bone marrow ${ }^{159}$, rat glaborous skin ${ }^{166}$, and keratinocytes ${ }^{163}$.

In the CNS, high affinity GluTPs located on adjacent neurons and surrounding glial cells rapidly remove Glu from the synaptic cleft to prevent cell death ${ }^{167-169}$. Five GluTPs, EAAT-1 (or GLAST), EAAT-2 (or GLT-1), EAAT-3 (or EAAC-1), EAAT-4, and EAAT-5, have been cloned $^{169-174}$.

GluTPs are pharmacologically distinct from both iGluRs and mGluRs and L-Glu, L-Asp, and D-Asp are substrates for the transporters ${ }^{129,130,175}$; GluR agonists ${ }^{129,130,175,176}$ and antagonists ${ }^{130,177}$ are not. Glu uptake can be blocked by the transporter blockers dihydrokainate (DHKA) and DL-threo- $\beta$-hydroxyaspartate (HA) ${ }^{130,177}$.

GluTPs incorporate Glu into cells along with the cotransport of three $\mathrm{Na}^{+}$ions ${ }^{175,178}$ and the antiport of one $\mathrm{K}^{+}$ ion ${ }^{178,179}$ and either one $\mathrm{OH}$ - or one $\mathrm{HCO}_{3}{ }^{-}$ion ${ }^{179}$. The excess $\mathrm{Na}^{+}$ions generate a net positive inward current, which drives the transporter ${ }^{175,178}$. In addition, a Glu-elicited chloride current is also associated with some transporters ${ }^{174,179}$.
GluTPs located in the plasma membrane of neuronal and glial cells are different from the GluTPs located on synaptic vesicles within presynaptic terminals. The transporters in the plasma membrane transport Glu in a $\mathrm{Na}^{+}$ and voltage-dependent manner independent of $\mathrm{Cl}^{-168,175,178}$. L-Glu, L-Asp, and D-Asp are substrates for these transporters ${ }^{175}$. In contrast, the vesicular transporter selectively concentrates Glu into synaptic vesicles in a $\mathrm{Na}^{+}$independent, ATP-dependent manner ${ }^{180-182}$ that requires $\mathrm{Cl}^{-}$ $181-185$.

The pharmacology of GluR is similar to that described for GluTPs, as the Glu-elicited current is dependent upon external $\mathrm{Na}^{+}$, reduced by transporter blockers, and insensitive to Glu agonists and antagonists. However, altering internal $\mathrm{Na}^{+}$concentration does not change the reversal potential ${ }^{183}$ or the amplitude ${ }^{185,186}$ of the Glu-elicited current, suggesting GluR is distinct from GluTPs.

\section{2) Gamma-Aminobutyric Acid (GABA)}

In $1950, \gamma$-Aminobutyric acid (GABA) was independently identified in the vertebrate brain ${ }^{187,188}$. These investigators also demonstrated the presence of glutamic acid decarboxylase (GAD) in mouse brain and showed that the active enzyme, capable of decarboxylating Glu to GABA, required pyridoxal 5-phosphate (PLP) as cofactor ${ }^{189}$.

Early electrophysiological work carried out, primarily in crustaceans, firmly established GABA as an inhibitory neurotransmitter in invertebrates ${ }^{190}$. Although GABA was originally shown to be present in very high, up to millimolar, concentrations in the vertebrate CNS, it proved considerably more difficult to unequivocally establish its role as a neurotransmitter in the mammalian brain. However, by the early 1970 s, GABA had been shown to satisfy all of the classical criteria of a neurotransmitter ${ }^{191,192}$.

The establishment of the role of GABA as a neurotransmitter was hampered by the widespread distribution of GABAergic neurons throughout the CNS, and the lack of suitable reagents to positively identify GABAergic neurons. The role of GABA as a neurotransmitter is that of inhibitory neurotransmission, although this property has been questioned recently ${ }^{193}$. Following the purification of GAD and the generation of GAD antisera, immunohistochemical studies revealed that many GABAergic neurons in the brain are interneurons and are therefore uniquely able to alter the excitability of local circuits within a given brain region ${ }^{192}$. From these and other studies it was confirmed that $30-40 \%$ of all CNS neurons utilize GABA as their primary neurotransmitter.

a) GABA: Synthesis, uptake, and metabolism

GABA is formed in vivo via a metabolic pathway called the "GABA shunt". The initial step in this pathway utilizes $\alpha$-ketoglutarate formed from glucose metabolism via the Krebs cycle. $\alpha$-Ketoglutarate is then transaminated by $\alpha$ oxoglutarate transaminase (GABA-T) to form Glu, the immediate precursor of GABA. Finally, Glu is decarboxylated to form GABA by the GAD ${ }^{189,192}$. GAD is expressed only in GABAergic neurons and in certain 
Table 2. A summary of the Functions and Molecular Structure of GABA Receptors

\begin{tabular}{|l|l|l|l|}
\hline \multicolumn{1}{|c|}{ Receptor } & \multicolumn{1}{|c|}{ Function } & \multicolumn{1}{|c|}{ Molecular structure } & \multicolumn{1}{c|}{ Other actions } \\
\hline GABA $_{\mathrm{A}}$ and GABA $\mathrm{C}$ & $\begin{array}{l}\text { GABA binding opens } \\
\mathrm{Cl}^{-} \text {channels. }\end{array}$ & $\begin{array}{l}\text { Heteropentamers of } \alpha 1-6, \\
\beta 1-4, \gamma 1-4, \delta, \text { and } \rho \\
\text { primarily in the retina. } \\
\text { Many receptor subtypes } \\
\text { contain } \alpha, \beta, \text { and } \gamma \text { in a } \\
\text { pentameric arrangement. }\end{array}$ & $\begin{array}{l}\text { In recombinant systems, both the } \alpha \text { and } \beta \text { subunits are required } \\
\text { for the benzodiazepine (valium and librium) site. Barbiturates } \\
\text { (Phenobarbital, pentobarbital) bind to } \alpha \text { and } \beta \text { subunits. } \\
\text { Both of these drugs enhance channel opening and the effect of } \\
\text { the drugs at any given synapse depends on the subunit } \\
\text { composition of the GABA receptors there. }\end{array}$ \\
\hline GABA $_{\mathrm{B}}$ & $\begin{array}{l}\text { These receptors are } \\
\text { largely inhibitory by } \\
\text { opening } \mathrm{K}^{+} \text {channels or } \\
\text { closing Ca } \mathrm{C}^{++} \text {channels. }\end{array}$ & $\mathrm{G}_{\mathrm{i} / \mathrm{o}}$ & Widely distributed throughout the brain \\
\hline
\end{tabular}

peripheral tissues, which are also known to synthesize GABA.

Like most neurotransmitters, GABA is stored in synaptic vesicles and is released in a $\mathrm{Ca}^{++}$-dependent manner upon depolarization of the presynaptic membrane. Following release into synaptic cleft, GABA's actions are terminated principally by reuptake into presynaptic terminals and surrounding glia. GABA is also metabolized by GABA-T to form succinic semialdehyde. This transamination regenerates Glu when it occurs in the presence of $\alpha$-ketoglutarate. Next, succinic semialdehyde is oxidized by succinic semialdehyde dehydrogenase (SSADH) to succinic acid, which then reenters the Krebs cycle.

The reuptake of GABA occurs via highly specific transmembrane transporters, which have recently been shown to be members of a large family of $\mathrm{Na}^{+}$-dependent neurotransmitter transporters. GABA uptake is temperatureand ion-dependent and both $\mathrm{Na}^{+}$and $\mathrm{Cl}^{-}$ions are required for optimal uptake.

Affinity purification of the GABA transporter protein has recently led to its molecular cloning ${ }^{194}$. The principal neuronal GABA transporter is a 70 - to $80-\mathrm{kDa}$ glycoprotein that contains 12 hydrophobic membrane-spanning domains. To date, at least two other GABA transporter cDNAs have been cloned ${ }^{195}$, but the physiological and pharmacological significance of this heterogeneity is unknown. Nonetheless, specific inhibitors of GABA uptake that directly bind to the transporter itself have been synthesized, and several have been shown to have anticonvulsant and antinociceptive properties in laboratory animals ${ }^{196,197}$.

b) GABA receptors

GABA is a highly flexible molecule and, thus, can exist in many low-energy conformations. Conformationally restricted analogues of GABA have been used to help identify three major GABA receptors, termed $\mathrm{GABA}_{\mathrm{A}}$, $\mathrm{GABA}_{\mathrm{B}}$ and $\mathrm{GABA}_{\mathrm{C}}$ receptors ${ }^{198-200}$. $\mathrm{GABA}_{\mathrm{A}}$ and $\mathrm{GABA}_{\mathrm{C}}$ receptors are members of a superfamily of transmitter-gated ion channels that include nicotinic acetylcholine, strychninesensitive glycine and $5 \mathrm{HT}_{3}$ receptors ${ }^{201,203}$. On the other hand, GABAB receptors are seven transmembrane receptors that are coupled to G-proteins and activate second messenger systems and $\mathrm{Ca}^{++}$and $\mathrm{K}^{+}$ion channels. These receptors

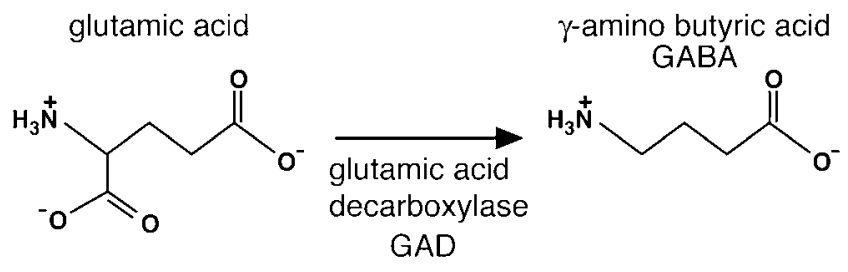

Fig. 4. Biotransformation of glutamic acid to GABA

resemble mGluRs and develop before GluR ${ }^{203}$.

c) $\mathrm{GABA}_{\mathrm{A}}$ receptors: physiology to pharmacology

$\mathrm{GABA}_{\mathrm{A}}$ receptors are hetero-oligomeric chloride channels that are selectively blocked by the alkaloid bicuculline and modulated by steroids, barbiturates and benzodiazepines ${ }^{204,205}$. To date, 16 human $\mathrm{GABA}_{\mathrm{A}}$ receptor cDNA have been cloned. They are ionotropic receptors leading to increased $\mathrm{Cl}^{-}$ion conductance ${ }^{206}$. Activation of the $\mathrm{GABA}_{\mathrm{A}}$ receptor by an agonist results in an increase in $\mathrm{Cl}^{-}$ion conductance via the receptor-gated ion channel or pore. This increase in $\mathrm{Cl}^{-}$ion conductance, which requires the binding and cooperative interaction of two molecules of GABA, is actually due to an increase in the mean open time of the $\mathrm{Cl}^{-}$ion channel itself ${ }^{206}$. The increase in $\mathrm{Cl}^{-}$ion conductance observed following activation of $\mathrm{GABA}_{\mathrm{A}}$ receptors results in a localized hyperpolarization of the neuronal membrane and therefore leads to an increase in the threshold required for excitatory neurotransmitters to depolarize the membrane in order to generate an action potential. This decrease in neuronal membrane excitability results in the inhibitory actions of GABA ${ }^{198}$.

A variety of GABA receptor agonists have been discovered and have been shown to selectively activate $\mathrm{GABA}_{\mathrm{A}}$ receptors. Muscimol, a rigid GABA analogue isolated from the hallucinogenic mushroom Amanita muscaria, is one of the most selective and potent GABA agonists known. Muscimol is also not a substrate for the GABA transporter, which makes it useful for electrophysiological and biochemical studies. Both competitive and noncompetitive $\mathrm{GABA}_{\mathrm{A}}$ receptor antagonists also have been described ${ }^{207}$. 
d) $\mathrm{GABA}_{\mathrm{A}}$ and $\mathrm{GABA}_{\mathrm{C}}$ receptor agonists and antagonists

It is believed that the $\mathrm{GABA}_{\mathrm{A}}$ receptor is a heteropentameric glycoprotein of approximately $275 \mathrm{kDa}^{202}$. Many compounds have been shown to augment GABAmediated $\mathrm{Cl}^{-}$ion conductance selectively at pharmacologically relevant concentrations. There is now considerable evidence that a number of other sedativehypnotic-anesthetic drugs also interact with GABA $_{A}$ receptors e.g., benzodiazepines, and several other compounds such as barbiturates, alcohols and anesthetics, have been shown to bind to, and affect, other receptors and channels as well. Therefore, the $\mathrm{GABA}_{\mathrm{A}}$ receptor can be positively or negatively modulated by compounds, which range in activity from full agonists to full inverse agonists $^{208,209}$. Full agonists have sedative- anesthetic properties, whereas full inverse agonists are convulsants ${ }^{210}$. It is now thought that $\mathrm{GABA}_{\mathrm{A}}$ receptors are involved in at least some forms of human anxiety.

The large numbers of drug recognition sites associated with $\mathrm{GABA}_{\mathrm{A}}$ receptors, which are clearly distinct from those that recognize GABA itself, have led several investigators to propose the existence of endogenous receptor ligands. Several have been identified; however, with the possible exception of two, there is little compelling evidence at present that any interact with $\mathrm{GABA}_{\mathrm{A}}$ receptors in vivo. One of these ligands is an endogenous peptide diazepam-binding inhibitor (DBI), which was shown to interact with $\mathrm{GABA}_{\mathrm{A}}$ receptors and to have anxiogenic properties similar to inverse agonists ${ }^{211}$. The other postulated endogenous ligands include two natural reduced steroid metabolites of progesterone and deoxycorticosterone: allopregnanalone and allotetrahydrodeoxycorticosterone ${ }^{212}$.

These neuroactive steroids bind with high affinity to $\mathrm{GABA}_{\mathrm{A}}$ receptors and have barbiturate-like actions in augmenting GABA-mediated responses ${ }^{213}$. The plasma and brain levels of these neuroactive steroids increase dramatically following exposure of rats to various stressors. Plasma allopregnanolone levels are also quite high during the third trimester of pregnancy, and they decrease dramatically following parturition ${ }^{213}$. However, none of these putative natural ligands have yet been unequivocally demonstrated to sub serve any physiological function.

Bicuculline is the prototypical competitive antagonist and directly competes with GABA for binding to the receptor complex. Bicuculline reduces both the frequency and mean open time of the GABA-gated $\mathrm{Cl}^{-}$ion channel. Picrotoxin and other extremely potent cage convulsants such as t-butylbicyclophosphorothionate (TBPS) are noncompetitive GABA receptor antagonists that do not compete directly with GABA for its recognition sites but, instead, bind to separate and distinct recognition sites associated with the receptor complex ${ }^{214}$.

Other selective antagonists, such as the imidazobenzodiazepine Ro15-1788 (flumazenil), bind with high affinity to $\mathrm{GABA}_{\mathrm{A}}$ receptors but are devoid of intrinsic activity of their own ${ }^{209}$. However, these antagonists completely block the actions of benzodiazepine receptor agonists in augmenting GABA-mediated responses. Selective antagonists such as flumazenil also reverse the actions of inverse agonists. Not surprisingly, both classes of $\mathrm{GABA}_{\mathrm{A}}$ receptor antagonists produce seizures when administered to laboratory animals. The affinity of convulsants for $\mathrm{GABA}_{\mathrm{A}}$ receptors is so high that they have proven to be useful radioligands for measuring $\mathrm{GABA}_{\mathrm{A}}$ receptors in vitro and for their subsequent biochemical and pharmacological characterization ${ }^{214}$.

Ethanol has been shown by several investigators to augment GABA-activated $\mathrm{Cl}^{-}$ion conductance in a variety of intact and isolated neuronal membrane preparations ${ }^{215}$. Concentrations of ethanol (10-100 mM) weakly augment GABA-activated $\mathrm{Cl}^{-}$ion conductance, as do longer chainlength alcohols and general anesthetics ${ }^{216,217}$. Moreover, several imidazobenzodiazepine inverse agonists of the benzodiazepine receptor have been reported to antagonize the sedative effects of ethanol ${ }^{215}$. This finding is further evidence implicating the $\mathrm{GABA}_{\mathrm{A}}$ receptor as one of the key central sites mediating at least some of ethanol's neuropharmacological effects. The effects of ethanol on $\mathrm{GABA}_{\mathrm{A}}$ receptors, coupled with its more recently described actions in inhibiting Glu (NMDA) receptor-mediated depolarizing events ${ }^{217}$, likely contribute to the anxiolytic and sedative effects of alcohols.

To date, five distinct classes of polypeptide subunits $(\alpha$, $\beta, \gamma, \delta$, and $\rho$ ) have been cloned and multiple isoforms of each have been shown to exist ${ }^{218}$. There is approximately $70 \%$ sequence identity between the polypeptide subunits within a given class, but only approximately $30 \%$ between classes $^{219-221}$. Subunit heterogeneity seems also to be relevant to the pharmacological differences observed between drugs that interact with $\mathrm{GABA}_{\mathrm{A}}$ receptors such as the benzodiazepines ${ }^{222,223}$.

Several of the subunits of the $\mathrm{GABA}_{\mathrm{A}}$ receptor have been cloned ${ }^{201,205}$. The deduced AA sequences of the $\alpha$ - and $\beta$-subunit cDNAs isolated indicated that each subunit was approximately $50-60 \mathrm{kDa}$ in size and had four $\alpha$-helical hydrophobic membrane-spanning sequences of approximately 20-30 AAs. The predicted structure of the receptor was based on strong evidence that the $\mathrm{GABA}_{\mathrm{A}}$ receptor is a member of a large superfamily of ligand-gated ion channels, which includes the nicotinic-cholinergic, ionotropic Glu, and glycine receptors ${ }^{201,202}$.

In contrast, $\mathrm{GABA}_{\mathrm{C}}$ receptors represent a relatively simple form of transmitter-gated $\mathrm{Cl}^{-}$ion channel made up of a single type of protein subunit. Two human $\mathrm{GABA}_{\mathrm{C}}$ receptor cDNA have been cloned ${ }^{200}$. These receptors are not blocked by bicuculline nor do steroids, barbiturates or benzodiazepines modulate them. Instead, $\mathrm{GABA}_{\mathrm{C}}$ receptors are selectively activated by the conformationally restricted analogues of GABA in the folded conformation cis-4aminocrotonic acid and (1 S, 2 R)-2-(aminomethyl)-1carboxycyclopropane. (1,2,5,6-Tetrahydropyridine-4-yl) methylphosphinic acid, a methylphosphinic acid analogue of GABA in a partially folded conformation, is a selective antagonist at GABAC receptors ${ }^{198,224}$. 
e) $\mathrm{GABA}_{\mathrm{B}}$ receptors

$\mathrm{GABA}_{\mathrm{B}}$ receptors are seven transmembrane receptors that are coupled to G-proteins and activate second messenger systems and $\mathrm{Ca}^{++}$and $\mathrm{K}^{+}$ion channels ${ }^{225}$. Three $\mathrm{GABA}_{\mathrm{B}}$ receptor proteins have been cloned and these resemble metabotropic GluRs ${ }^{199,226}$. GABA ${ }_{B}$ receptors are heterooligomeric receptors made up of a mixture of a combination of the subunits, which are selectively activated by baclofen and CCGP27492 and are blocked by phaclofen, the phosphonic acid analogue of baclofen; hence, $\mathrm{GABA}_{\mathrm{B}}$ is found in central and peripheral nervous tissue ${ }^{226}$.

\section{3) Glycine}

Glycine (Gly), also known as aminoethanoic acid, is a non-polar, sweet tasting, AA derived from the alkaline hydrolysis of gelatin. It is the simplest of the AAs as its side chain is only a hydrogen atom. More complex AAs are constructed on the basic glycine structure. Since Gly has no side chain, it can enter spaces where no other AA can, e.g., only glycine can be the internal AA of the collagen helix accounting for about one third of the mass of collagen. Gly is conserved among species at certain positions in some proteins, e.g., cytochrome c, myoglobin, and hemoglobin ${ }^{227}$. a) Glycine: synthesis and uptake

Gly is the major inhibitory neurotransmitter in the brainstem and spinal cord, where it participates in a variety of motor and sensory functions. It also functions as a co agonist at the NMDA subtype of GluR in the forebrain, where it promotes the actions of Glu, the major excitatory neurotransmitter. Thus, Gly subserves both inhibitory and excitatory functions within the CNS.

Gly is formed from serine by the enzyme serine hydroxymethyltransferase (SHMT) and like GABA, is released from nerve endings in a $\mathrm{Ca}^{++}$-dependent fashion. Its uptake has been demonstrated in the brainstem and spinal cord in regions where there are also high densities of inhibitory glycine receptors. The actions of Gly are terminated primarily by reuptake via $\mathrm{Na}^{+} / \mathrm{Cl}^{-}$-dependent, high-affinity glycine transporters.

Glycine transporters have been cloned and expression shown in the CNS and in peripheral tissues ${ }^{228,229}$. These glycine transporters are members of the large family of $\mathrm{Na}^{+} /$ $\mathrm{Cl}^{-}$-dependent neurotransmitter transporters, and both share approximately $50 \%$ sequence identity with the GABA transporters discussed above. Two glycine-cloned transporters have been named GLYT-1 and GLYT-2 both of which have similar kinetic and pharmacological properties $^{228}$. Studies have inferred that GLYT-1 is primarily a glial glycine transporter whereas GLYT-2 is primarily a neuronal transporter. The mapping of both glycine transporter mRNAs, as well as the glycine receptor subunit mRNAs, confirm the importance of this neurotransmitter in the brainstem and spinal cord, but support a more widespread distribution in supraspinal brain regions than was previously suspected ${ }^{230}$.

b) Glycine receptors

The glycine receptor was first successfully dissolved

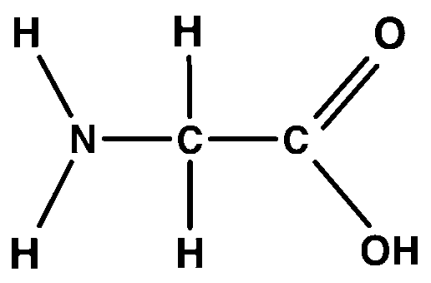

Fig. 5. Structure of glycine, which is a simple amino acid

and purified using affinity purification over an affinity matrix derivatized with aminostrychnine ${ }^{231}$. This affinitypurified glycine receptor was shown to consist of two polypeptide subunits of approximately $48 \mathrm{kDa}(\alpha)$ and 58 $\mathrm{kDa}(\beta)$, respectively.

Reconstitution of these polypeptide subunits into lipid vesicles resulted in functional receptors, and intramolecular cross-linking experiments suggested that the native glycine receptor is a pentameric structure. Photo affinity labeling of the glycine receptor with $\left[{ }^{3} \mathrm{H}\right]$ strychnine revealed that both the strychnine and Gly binding sites are located on the $48-\mathrm{kD}$ a subunit. As would be expected, purification of the $\alpha$-and $\beta$-receptor subunits was followed closely by their molecular cloning ${ }^{231}$.

The deduced AA sequences of the $\alpha$ - and $\beta$-glycinereceptor subunits predict structures quite homologous to the subunits of other ligand-gated ion channels, including the $\mathrm{GABA}_{\mathrm{A}}$ receptor $^{232}$. Each subunit has four hydrophobic membrane-spanning sequences, and each shares considerable sequence identity with the other. Several glycine-receptor $\alpha$-subunit variants have been identified $(\alpha 1-4)$, and, not surprisingly, they differ in their pharmacological properties and level of expression. As mentioned, both the agonist and antagonist binding sites are located on the $\alpha$-subunit, but at different $\mathrm{AAs}^{233}$.

Interestingly, glycine receptors comprised of $\alpha 1$ subunits are efficiently gated by taurine and $\beta$-alanine, whereas $\alpha 2$-containing receptors are not ${ }^{231}$. The $\alpha 1$ and $\alpha 2$ genes are expressed in the adult and neonatal brain, respectively. Here the $\beta$-subunit transcript is expressed at relatively high levels in the cerebral cortex and cerebellum, where no a transcripts or specific $\left[{ }^{3} \mathrm{H}\right]$ strychnine binding sites have been observed. Co expression of $\beta$ subunits with $\alpha$-subunits, as opposed to homo-oligomeric $\alpha$-subunit glycine receptors, results in glycine receptors with pharmacological properties quite similar to native glycine receptors. Nonetheless, the widespread distribution of $\beta$ subunit mRNA in the brain suggests that other, perhaps strychnine-insensitive glycine receptor isoforms will be found.

The expression of $\alpha 1$ and $\alpha 2$ subunits is regulated developmentally with a switch from the neonatal $\alpha 2$ subunit [strychnine-insensitive] to the adult $\alpha 1$ form [strychninesensitive] at about 2 weeks postnatally in the mouse $\mathrm{e}^{231}$. The timing of this switch over corresponds with the development of spasticity in the mutant spastic mouse ${ }^{234}$, prompting speculation that insufficient expression of the adult isoform 
Table 3. The Function and Structure of Glycine Receptors

\begin{tabular}{|l|l|l|l|}
\hline Receptor & \multicolumn{1}{|c|}{ Function } & Molecular structure & \multicolumn{1}{c|}{ Other actions } \\
\hline Glycine & $\begin{array}{l}\text { Glycine binding opens } \\
\mathrm{Cl}^{-} \text {channels. }\end{array}$ & $\begin{array}{l}\text { Heteropentamers of } \\
\alpha 1-4, \text { and } \beta .\end{array}$ & $\begin{array}{l}\text { Strychnine is the most potent and } \\
\text { selective competitive antagonist. }\end{array}$ \\
\hline
\end{tabular}

may underlie some forms of spasticity ${ }^{230}$.

Electrophysiological studies in rodent spinal cord neurons have demonstrated that Gly activates the $\mathrm{Cl}^{-}$ion conductance ${ }^{231}$. Like GABA, this increase in $\mathrm{Cl}^{-}$ion conductance results in a hyperpolarization of the neuronal membrane and an antagonism of other depolarizing stimuli. As indicated above, other $\alpha$ - and $\beta$-AAs, including $\beta$-alanine and taurine, also activate glycine receptors, but with lower potency ${ }^{231,235}$. Inhibitory glycine receptors are blocked by the plant alkaloid strychnine, which was also first used to label glycine receptors in spinal cord membranes ${ }^{217,236}$. Strychnine poisoning results in muscular contractions and tetany as a result of glycinergic disinhibition and over excitation.

c) Glycine as a co-agonist

Gly is a co-agonist at NMDA receptors at a strychnineinsensitive recognition site (glycine B) and its presence at moderate $\mathrm{nM}$ concentrations is a prerequisite for channel activation by Glu or NMDA ${ }^{237}$. Physiological concentrations reduce one form of relatively rapid NMDA receptor desensitization.

Recently it has been suggested that D-serine may be more important than Gly as an endogenous co-agonist at NMDA receptors in the telencephalon and developing cerebellum. There is still some debate as to whether the glycine B site is saturated in vivo ${ }^{237}$ but it seems likely that the degree of NMDA receptor activation varies depending on regional differences in receptor subtype expression and local Gly or D-serine concentrations. Moreover, Gly concentrations at synaptic NMDA receptors could be finely modulated by local expression of specific glycine transporters such as GLYT1 ${ }^{238}$.

\section{Glutamate Receptors}

Glutamate receptors (GluRs), which are important in neural plasticity, neural development, and neurodegeneration ${ }^{239-241}$, have been individually characterized by their sensitivity to specific Glu analogues and by the features of the Glu-elicited current. GluR agonists and antagonists are structurally similar to Glu, which allows them to bind onto the same receptors ${ }^{242-244}$. Activation of GluRs has been shown to mediate a large number of neuronal processes such as long-term potentiation and ischemic damage ${ }^{245}$.

Two classes of GluRs have been characterized based on studies in the CNS: ionotropic (iGluRs) and metabotropic (mGluRs). These receptor types are similar in that they both bind Glu, and Glu binding can influence the permeability of ion channels. However, there are several differences between the two classes ${ }^{246}$. Their cloning has revealed the molecular diversity of the gene families encoding various receptor types that are responsible for the pharmacological and functional heterogeneity in the brain and other tissues $^{21,24-26,31,33,55,56,156}$.

\section{Ionotropic glutamate receptors (iGluRs)}

The iGluRs are ligand-gated ion channels that mediate the vast majority of excitatory neurotransmission in the brain. The iGluRs contain integral cationic channels associated with ligand binding sites that mediate rapid synaptic transmission. The structure and how it relates to the function of these receptors has received recent attention and the reader is directed to these publications for further details $^{247-249}$.

The iGluR family is classified into three major subtypes according to their sequence similarities, their electrophysiological properties, and their affinity to selective agonists: $N$-methyl-D-aspartate (NMDA), $\alpha$-amino-3hydroxy-5-methyl-4-isoxazole propionic acid (AMPA) and kainate $(\mathrm{Ka})$ receptors ${ }^{21,22,25,26}$.

All iGluRs can form heteromeric subunit assemblies, composed of different subunits, which have different physiological and pharmacological properties and are differentially distributed throughout the $\mathrm{CNS}^{25,50,237,250-253}$. Both AMPA $^{254}$ and NMDA receptors ${ }^{255}$ are probably largely formed from tetrameric, heteromeric assemblies of different subunits $^{256}$. Changes in these receptors are probably mediated through nuclear transcription factors ${ }^{257}$.

The membrane channels associated with these receptors exhibit varied pharmacological and electrophysiological properties, including ionic channel selectivity to sodium $\left(\mathrm{Na}^{+}\right)$, potassium $\left(\mathrm{K}^{+}\right)$and $\mathrm{Ca}^{++21,22,25,26,33}$. The non-NMDA receptors control a nonselective cationic channel permeable to $\mathrm{Na}^{+}$and $\mathrm{K}^{+}$, whereas NMDA is more permeable to $\mathrm{Ca}^{++}$ ions than either AMPA or $\mathrm{Ka}^{21,22,25,26}$.

Recombinant technology has identified several gene families encoding iGluRs: AMPA family is composed of GluR 1-4 (GluRA-D); Ka family includes GluR 5-7 and Ka 1-2; NMDA includes NMDAR 1 and NMDAR 2A-D.

NMDAR 1, the most tightly regulated neurotransmitter receptor, forms the channel where other subunits (NMDA 2A-D) are involved in the receptor modulation. It is the most intensively studied and complex receptor and is linked to the $\mathrm{Na}+$ and $\mathrm{Ca}^{++}$ion channel that has 5 distinct binding sites for endogenous ligands that influence the opening of these channel $^{21,22,25,33}$. These binding sites include 2 different agonist recognition sites, one for Glu and one for Gly, a polyamine regulatory site that promotes receptor activation. The remaining sites are separate recognition sites for $\mathrm{Mg}^{++}$, 


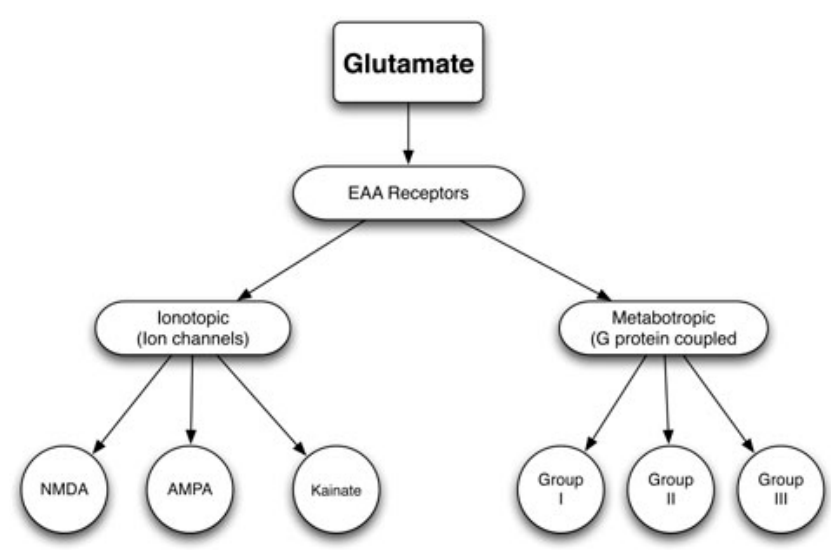

Fig. 6. Relationship of glutamate receptors to one another

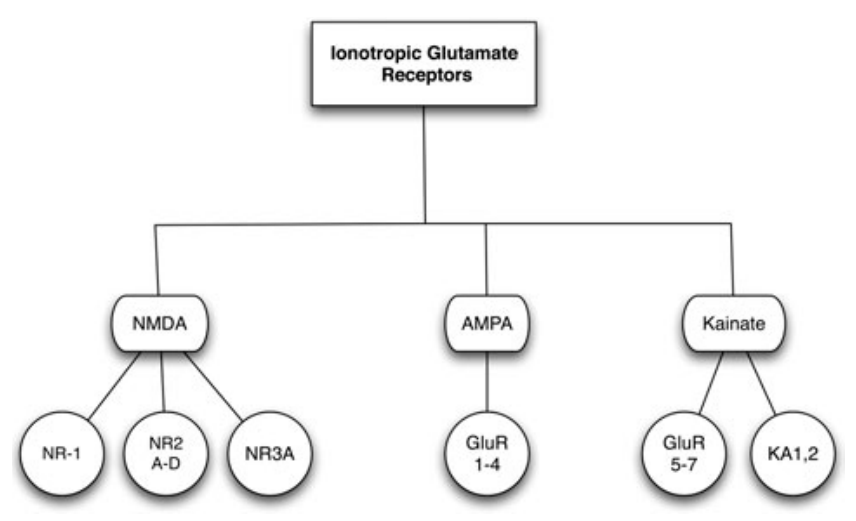

Fig. 7. Relationship of ionotropic glutamate receptors to one another

$\mathrm{Zn}^{++}$, and phencyclidine (PCP), which inhibits ion flux through agonist bound receptors ${ }^{21,22,25,26,33,250}$.

The complexity of these iGluR families is further increased by alternate splicing, RNA editing and posttranslational modifications such as phosphorylation, glycosylation and palmitoylation. Each of these modifications is important in the regulation of channel functions ${ }^{247,248}$.

Within each family, GluRs subunits can also form homo-oligomeric or heteroligomeric channels that exhibit different functional properties depending on the subunit composition. For example, the presence of the GluR 2 subunit decreases $\mathrm{Ca}^{++}$permeability of AMPA channels ${ }^{21,22,25,33}$. Table 4 lists the iGluRs.

Learning and memory depend on persistent changes in synaptic strength that require neuronal gene expression. AMPA- and NMDA-type GluRs have distinct roles in controlling synaptic strength: AMPA receptors effect shortterm changes in synaptic strength, whereas NMDA receptors regulate genes that are required for the long-term maintenance of these changes ${ }^{259}$.

1) Diversity of the ionotropic glutamate receptors

The iGluRs are an extremely diverse group of receptors, a diversity that is generated both before and after gene transcription. Glu binding onto an iGluR directly influences ion channel activity because the receptor and the ion channel form one complex. These receptors mediate fast synaptic transmission between neurons. Each iGluR is formed from the co-assembly of multimeric individual subunits, the structures of which affect the receptor function ${ }^{249}$.

The assembled subunits may or may not be homologous, with the different combinations of subunits, e.g., NR2A-D is produced from four genes, resulting in channels with different characteristics ${ }^{57,240,260-263}$. However, following gene transcription, the resultant pre-mRNA may be modified. For example, different regions of this mRNA molecule can be spliced together, giving rise to multiple mRNAs that are translated into different proteins.

This phenomenon is known as "splice variation" and is a very common finding among neuroreceptors. The Cterminus of the iGluRs is the site of extensive splice variation, which could have important functional consequences, as the C-terminus is also the site for multiple protein-protein interactions, e.g., GluR2. Thus, different splice variants may interact differently with the same set of proteins leading to, for instance, differential subunit localization $^{246}$.

A further modification leading to diversification is RNA editing, in which selected nucleotides in the mRNA sequence transcribed from the gene sequence are enzymatically modified, changing the AA for which it was coded. Such an event has fundamental consequences for the $\mathrm{Ca}^{++}$permeability of subunits such as the AMPA type subunit GluR2 and the Ka receptor subunit GluR5 ${ }^{264}$.

\section{2) Synaptic plasticity}

In many regions of the $\mathrm{CNS}$, limited $\mathrm{Ca}^{++}$influx through NMDA receptors can trigger two forms of synaptic plasticity: LTP and LTD. LTP and LTD are believed to resemble some elementary features of memory formation at the neuronal leve $\mathrm{e}^{191,265-269}$.

Voltage-dependent blockade of NMDA receptors by $\mathrm{Mg}^{++}$and their high $\mathrm{Ca}^{++}$permeability renders them inherently suited for their role in mediating synaptic plasticity $^{271}$. NMDA receptor channels are only activated in the presence of a local strong depolarization induced by strong AMPA receptors activation and concurrent GABAergic disinhibition via feedback effects of GABA on $\mathrm{GABA}_{\mathrm{B}}$ autoreceptors.

As a result, the $\mathrm{Mg}^{++}$blockade of NMDA receptors is transiently fully relieved allowing $\mathrm{Ca}^{++}$to flow into the postsynaptic neuron. This $\mathrm{Ca}^{++}$influx triggers a cascade of secondary messengers which ultimately activate a number of enzymes such as protein kinase $\mathrm{C}$ (PKC), phospholipase A2 (PLA2), phospholipase C (PLC), $\mathrm{Ca}^{++}$-calmodulindependent protein kinase II (CaM kinase II), and others ${ }^{272-}$ 278. Consequently, these processes lead to fixation of changes in postsynaptic AMPA receptors such as an increase in their affinity and number ${ }^{279-283}$, and possibly through retrograde signals from arachidonic acid and nitric oxide ${ }^{284}$, modulate presynaptic glutamatergic terminals influencing 
Table 4. Ionotropic Receptors, Their Subunits, Agonists and Antagonists

\begin{tabular}{|l|l|l|l|}
\hline Receptor & NMDA & AMPA & Kainate \\
\hline Subunits & NR1, NR2A, NR2B, NR2C, NR2D & GLUR1, GLUR2, GLUR3, GLUR4 & GLUR5, GLUR6, GLUR7, KA1, KA2 \\
\hline Agonists & N-Methyl-D-aspartate & $\begin{array}{l}\alpha \text {-amino-3-hydroxy-5-methyl-4-isoxazole } \\
\text { propionic acid }\end{array}$ & Kainate \\
\hline Antagonists & D (-)-AP-5, D(-)-AP-7 & CNQX, DNQX & CNQX, DNQX \\
\hline
\end{tabular}

Table 5. Summary of iGluRs, Their Function and Structure

\begin{tabular}{|c|c|c|c|}
\hline Receptor & Function & Molecular structure & Other actions \\
\hline NMDA & $\begin{array}{l}\text { Glu binding opens cation-selective channels. The } \\
\text { receptors are identified pharmacologically by the agonist } \\
\text { action of N-methyl-D-aspartate (NMDA). } \mathrm{Ca}^{++} \text {is an } \\
\text { important charge carrier at depolarized potentials. Thus, } \\
\text { activation of NMDA receptors can raise intracellular } \mathrm{Ca}^{++} \text {, } \\
\text { which can act as a second messenger. The kinetics of } \\
\text { gating is relatively slow compare to those of the AMPA/ } \\
\text { kainite receptors. } \\
\text { The entry of } \mathrm{Ca}^{++} \text {(and } \mathrm{Na}^{+} \text {) through the channels is } \\
\text { subject to a voltage dependent block by } \mathrm{Mg}^{++} \text {such that } \\
\text { there is significant } \mathrm{Ca}^{++} \text {entry only if the neuron is } \\
\text { depolarized. The depolarization can be achieved by the } \\
\text { action of the AMPA receptor channels and, to a lesser } \\
\text { extent, by the NMDA receptor channels. The channels } \\
\text { also require the presence of glycine as a coagonist. }\end{array}$ & $\begin{array}{l}\text { Heterotetramers or heteropentamers of R1, } \\
\text { R2A, R2B, R2C, and R2D. } \\
\text { Alternatively known as NR1, NR2A-NR2D } \\
\text { and MDAR1, NMDAR2A-NMDAR2D. } \\
\text { Numerous splice variants can be mixed and } \\
\text { matched. }\end{array}$ & \\
\hline $\begin{array}{l}\text { AMPA/ } \\
\text { Kainate (Ka) } \\
\text { (non-NMDA) }\end{array}$ & $\begin{array}{l}\text { AMPA and kainite are a family of ligand-gated that are } \\
\text { activated physiologically by Glu. They are identified } \\
\text { pharmacologically by agonist actions of AMPA and } \\
\text { kainate and their insensitivity to NMDA. } \\
\text { Agonist binding opens cation channels that pass } \mathrm{Na}^{+}, \mathrm{K}^{+} \text {, } \\
\text { and sometimes } \mathrm{Ca}^{++} \text {. The kinetics of the response is fast } \\
\text { (quick on and quick off) compared to those of NMDA } \\
\text { receptors. Thus, they are very effective at depolarizing } \\
\text { neurons and mediate fast EPSCs. Previously, what is now } \\
\text { called AMPA/kainate receptors formed two classes based } \\
\text { on pharmacology: kainate receptors and AMPA/kainate/ } \\
\text { quisqualate receptors. More recently, molecular } \\
\text { classification has grouped these into a single group. }\end{array}$ & $\begin{array}{l}\text { Multi subunit tetramers or pentamers of } \\
\text { GluR } 1 \text { - GluR7, KA1, KA2. There is a } \\
\text { variety of molecular mechanisms result in } \\
\text { numerous splice variants of these proteins. } \\
\text { In addition, the GluR and Ka proteins can } \\
\text { combine in numerous ways. } \\
\text { The presence of a Ka subunit is sufficient } \\
\text { but not necessary to make a channel with } \\
\text { high sensitivity to kainate. }\end{array}$ & $\begin{array}{l}\text { Kainate is a potent } \\
\text { convulsant and } \\
\text { neurotoxin. } \\
\text { AMPA antagonists } \\
\text { are neuroprotective } \\
\text { in animal models of } \\
\text { cerebral ischemia. }\end{array}$ \\
\hline
\end{tabular}

transmitter release ${ }^{285-290}$.

There is accumulating evidence that LTP and LTD share some common mechanisms, although LTD occurs with increases in postsynaptic $\mathrm{Ca}^{++}$, which are insufficient to induce LTP $^{291-300}$. LTP and LTD have been extensively studied as cellular models of learning and memory.

Although hippocampal LTP and spatial learning are impaired by NMDA receptor blockade ${ }^{270}$, learning deficits can be almost completely prevented if rats are previously trained in a different water maze $\mathrm{e}^{301,302}$. Therefore, NMDA receptors may not be required for encoding the spatial representation of a specific environment but rather in other forms of memory important for learning this task ${ }^{303}$. Further evidence indicates that LTP is not only important for synaptic plasticity in the mature CNS but also in the formation of conducting glutamatergic synapses in the developing mammalian brain ${ }^{397}$.

One form of hippocampal LTP involves the activation of the NMDA receptors and a rise in postsynaptic $\mathrm{Ca}^{++}$in the
CA1 region but there is still considerable debate as to the site at which the increase in synaptic strength is expressed ${ }^{304-307}$. Presynaptic mechanisms, which can be measured at excitatory synapses on cultured hippocampal neurons by analysis of the progressive block of NMDA receptormediated synaptic currents by the irreversible open channel blocker, dizocilpine $((+)$ MK-801), should be reflected in a change in release probability ${ }^{398}$.

This technique was used to demonstrate that release probability was not affected after the induction of LTP, making a presynaptic mechanism unlikely ${ }^{308}$. In fact, other authors indicate that a high proportion of synapses in hippocampal area CA1 transmit through NMDA receptors but not AMPA receptors, making these synapses effectively non-functional at normal resting potentials due to $\mathrm{Mg}^{++}$ blockade ${ }^{309-312}$. These silent synapses acquire AMPA-type responses following LTP induction.

This form of LTP is accompanied by an increase in the conductance of postsynaptic AMPA receptors ${ }^{313}$. When 
viewed together, these findings challenge the dogma that LTP in CA1 involves a presynaptic modification, and suggest instead a simple postsynaptic mechanism for both induction and expression of LTP.

\section{3) NMDA receptors}

The NMDA receptor is perhaps the best characterized of the $\mathrm{iGluR}^{251,314}$, in part due to the existence of selective agonists and antagonists. NMDA receptors are ubiquitous ${ }^{315}$ and are found with relative ease in the cerebral cortex within the Schaffer collaterals of the CA3 - CA1 projection within the hippocampus. These receptors play a role in LTP; a phenomenon associated with learning and memory function and increased neuronal activity such as in "kindling."

NMDA receptors are quite diverse ${ }^{316}$ and are composed of assemblies of NR1 subunits and NR2 subunits, which can be one of four separate gene products (NR2A-D). Expression of both subunits is required to form functional channels. The Glu-binding domain of the receptor is formed at the junction of NR1 and NR2 subunits; hence, the need for expression of both subunits. In addition to Glu, the NMDA receptor requires a co-agonist, Gly, to bind to allow the receptor to function. The Gly-binding site is found on the NR1 subunit. The NR2B subunit also possesses a binding site for polyamines, regulatory molecules that modulate the functioning of the NMDA receptor ${ }^{317}$.

NMDA receptors are inactive at resting membrane potentials due to a voltage-dependent block of ion flow through the channel pore by $\mathrm{Mg}^{++}$ions. Sustained activation of AMPA receptors by a train of impulses arriving at a presynaptic terminal depolarizes the post-synaptic cell, releasing the channel inhibition and thus allowing NMDA receptor activation. Unlike GluR2-containing AMPA receptors, NMDA receptors are permeable to $\mathrm{Ca}^{++}$and other ions. Therefore NMDA receptor activation leads to a $\mathrm{Ca}^{++}$ influx into the post-synaptic cells.

Glu binding onto an NMDA receptor also opens nonselective cation channels, resulting in a conductance increase. However, the high conductance channel associated with these receptors is more permeable to $\mathrm{Ca}^{++}$than $\mathrm{Na}^{+}$ ions $^{318}$ and NMDA-gated currents typically have slower kinetics than kainate- and AMPA-gated channels. As the name suggests, NMDA is the selective agonist at these receptors. The compounds MK-801, AP-5 (2-amino-5phosphonopentanoic acid), and AP-7 (2-amino-7phosphoheptanoic acid) are NMDA receptor antagonists.

NMDA receptors are structurally complex, with separate binding sites for Glu, Gly, $\mathrm{Mg}^{++}, \mathrm{Zn}^{++}$, and a polyamine recognition site. There is also an antagonistbinding site for PCP and MK-801 ${ }^{319}$. The Glu, Gly, and $\mathrm{Mg}^{++}$binding sites are important for receptor activation and gating of the ion channel. In contrast, the $\mathrm{Zn}^{++}$and polyamine sites are not needed for receptor activation, but affect the efficacy of the channel.

$\mathrm{Zn}^{++}$blocks the channel in a voltage-independent manner ${ }^{320}$, whereas the polyamine site s21,322 $^{3 i n d s}$ compounds such as spermine or spermidine, either potentiating ${ }^{321,322}$ or inhibiting ${ }^{322}$ the activity of the receptor. Potentiation or inhibition depends on the combination of subunits forming each NMDA receptor ${ }^{322}$.

The Glu, Gly, and $\mathrm{Mg}^{++}$binding sites confer both ligand-gated and voltage-gated properties onto NMDA receptors. NMDA receptors are ligand-gated because the binding of GluR (ligand) is required to activate the channel with the presence of micromolar concentrations of Gly, which must also be present ${ }^{323,324}$. The requirement for both Glu and Gly makes them co-agonists ${ }^{324}$ at NMDA receptors. $\mathrm{Mg}^{++}$ions provide a voltage-dependent block of NMDAgated channels ${ }^{325}$.

NMDA receptors are highly permanent for $\mathrm{Ca}^{++}$ions. They show slower gating kinetics with the channel blocked in a voltage and use-dependent manner by physiological concentrations of $\mathrm{Mg}^{++}$ions ${ }^{325}$. These properties make them ideally suited for their role as a coincidence detector underlying synaptic plasticity in learning, chronic pain, drug tolerance and dependence $83,84,90,91,252,266$.

NDMA receptors were originally thought to belong exclusively in neurons. However, recent studies have found functional NMDA receptors in brain microglia, astrocytes, and oligodendrocytes, but glial and neuronal NMDA receptors are functionally and structurally different. Glial receptors are weakly sensitive to the extracellular $\mathrm{Mg}^{++}$ block in comparison to neurons, indicating a predominant expression of the NR3 receptor subunit.

In the cortex, astroglial NMDA receptors are activated upon physiological synaptic transmission. The physiological relevance of NMDA receptors in the white matter remains unknown; their activation upon ischemia triggers $\mathrm{Ca}^{++}$-dependent damage of oligodendrocytes and myelin ${ }^{326}$

a) NDMA subunits

Two major subunit families of NMDA designated NR1, NR2, as well as a modulatory subunit designated NR3, have been cloned. Most NMDA functional receptors are formed by combination of NR1 and NR2 subunits, which express the Gly and Glu recognition sites respectively ${ }^{327,328}$. NR1 is more concentrated in rostral structures such as cortex, caudate, and hippocampus, while the latter are principally found in more caudal regions such as thalamus ${ }^{329}$, colliculi, locus coeruleus and cerebellum ${ }^{330}$. The NR2 subfamily consists of four individual subunits: NR2A to NR2D 263 . Various heteromeric NMDA receptor channels formed by combinations of NR1 and NR2 subunits are known to differ in gating properties, $\mathrm{Mg}^{++}$sensitivity, and pharmacological profile $^{331}$. Of the NR2 group, NR2A is distributed ubiquitously, as is NR1, with greatest densities occurring in hippocampal regions. NR2B is expressed predominantly in forebrain but not in cerebellum where NR2C predominates. The spinal cord expresses high levels of NR2C and NR2D ${ }^{332}$ and these subunits may form heteroligomeric receptors with NR1 plus NR2A, which would provide a basis for the development of drugs selectively aimed at spinal cord disorders ${ }^{33}$. NR3 (NRL or Chi-1) is expressed predominantly in the developing CNS. NR3 does not seem 
to form functional homomeric Glu-activated channels, but the co-expression of NR3 with NR1 plus NR2 subunits decreases any response magnitude ${ }^{334-337}$.

\section{4) AMPA receptors}

AMPA receptors are involved in mediating most forms of fast glutamatergic neurotransmission, which corresponds to a $\mathrm{Ca}^{++}$influx ${ }^{338}$, and the inward rectification of both AMPA and kainate subtype GluRs are generated by polyamine-mediated ion channel block ${ }^{339}$. In fact, AMPA receptor activates a G-protein that suppresses a cGMP-gated current ${ }^{340}$.

Four known subunits GluR1 to GluR4, sometimes referred to as GluRA to GluRD, are widely, but differentially, distributed throughout the $\mathrm{CNS}^{25}$. The types of subunits forming these receptors determine their biophysical properties and pharmacological sensitivity.

Two alternative splice variants of GluR1 to GluR4 subunits designated as 'flip' and 'flop' have been shown to differ in their expression throughout the brain and during development and to impart different pharmacological properties AMPA receptors also play an important role in memory function ${ }^{341,342}$. They are localized in the hippocampus and striatum and also may play a role in the generation of seizures ${ }^{263,338,343}$.

Like all iGluR subunits, but in contrast to other ligand gated ion channel subunits such as those forming the $\mathrm{GABA}_{\mathrm{A}}$ receptor, iGluR subunits have an extracellular Nterminus and an intracellular $\mathrm{C}$-terminus. The ligandbinding domain is made up from $\mathrm{N}$-terminal regions $\mathrm{S} 1$ and $\mathrm{S} 2$, although it is possible that the binding site is spread across more than one subunit like the NMDA receptor. All AMPA receptor subunits exist as two splice variants, flip and flop. The alternative splice cassette is found at the Cterminal end of the loop between TMIII and TMIV. Although only a few AAs are changed in the receptor subunits, the effect can be quite dramatic resulting in altered desensitization kinetics.

Native AMPA receptor channels are impermeable to $\mathrm{Ca}^{++}$, a function controlled by the GluR2 subunit. The $\mathrm{Ca}^{++}$ permeability of the GluR2 subunit is determined by posttranscriptional editing of the GluR2 mRNA, which changes a single AA in the TMII region from glutamine (Q) to arginine $(R)$. This event is the so-called $Q / R$ editing site GluR2(Q) is $\mathrm{Ca}^{++}$permeable whilst GluR2(R) is not. Almost all the GluR2 protein expressed in the CNS is in the GluR2(R) form, giving rise to $\mathrm{Ca}^{++}$impermeable AMPA receptors. This observation, along with the interactions with other intracellular proteins, makes GluR2 perhaps the most important AMPA receptor subunit.

\section{5) Kainate receptors}

Kainate $(\mathrm{Ka})$ receptors constitute a separate group from the NMDA and AMPA receptors, although they share many of the same structural characteristics ${ }^{344}$. Ka and AMPA receptors are localized in the hippocampus and striatum and also may play a role in the generation of seizures ${ }^{345}$. Ka is used as a neurotoxin in basic research due to its ability to destroy cells at the site of injection while leaving axons of passage intact.

Ka receptors are built from multimeric assemblies of GluR5-7 and KA-1/2 subunits. Like the other iGluRs, they possess an extracellular $\mathrm{N}$-terminus. This terminus forms the ligand binding domain and a re-entrant loop (TMII), together with a loop between TMIII and TMIV, which forms the lining of the pore region in the ion channel. Ka also undergoes both splice variation and RNA editing, giving rise to a large number of possible receptors with differing pharmacological and functional properties ${ }^{346}$.

Ka receptors were previously believed to be largely presynaptic. Activation of these Ka receptors facilitated transmitter release at such sites as the dorsal root ganglia ${ }^{347}$. Short-term synaptic facilitation is reduced in knockout mice lacking the GluR6, but not the GluR5, Ka receptor subunit suggesting that $\mathrm{Ka}$ receptors act as presynaptic autoreceptors on mossy fiber terminals to facilitate synaptic transmission $^{348}$, but inhibition of GABA release ${ }^{349}$. Also they are involved post synaptically in neurotransmission in some pathways ${ }^{345,350-352}$.

\section{Metabotropic glutamate receptors ( $m$ GluRs)}

The mGluRs were discovered and established as a new type of excitatory AA receptor by their unique coupling mechanism and pharmacological characteristics. mGluRs are a family of eight single polypeptide chain receptors that function via coupling to G-proteins ${ }^{353}$. Members of this family have unique pharmacological properties and function to modulate the presynaptic release of Glu and the postsynaptic sensitivity of the cell to Glu excitation ${ }^{22,25,33,34,354,356}$. They exert their effects either on the second messengers or ion channels via the activation of the GTP-binding proteins and regulate the synthesis of different intracellular second messengers such as IP3, cAMP or cGMP2,25,33,34,56. Single mGluR proteins can cross talk with multiple second messengers in the same cell.

The mGluRs are densely expressed in medium spiny projection neurons of striatum. They have both chemical and electrical signaling properties ${ }^{355}$. Glu binding onto an mGluR opens non-selective cation channels more permeable to $\mathrm{Na}^{+}$and $\mathrm{K}^{+}$ions than $\mathrm{Ca}^{++318}$. mGluR binding elicits a rapidly activating inward and outward current and $\mathrm{Ka}$, quisqualate, and AMPA are the specific agonists at these receptors; CNQX (6-cyano-7-nitroquinoxaline-2, 3-dione), NBQX (1,2,3,4-tetrahydro-6-nitro-2,3-dionebenzo[f]quinoxaline-7-sulfonamide), and DNQX $(6,7-$ dinitroquinoxaline-2,3-dione) are the antagonists ${ }^{107,356-361}$.

In common with other G-protein coupled receptors (GPCRs), the mGluRs possess a 7 transmembrane domain motif (7-TMR) and an extracellular N-terminus and intracellular C-terminus. However, the mGluRs are much larger than GPCRs of the adrenergic type and the ligandbinding domain is located in the N-terminus, rather than in a pocket formed from the clustering of the 7-TMR region ${ }^{362}$. The eight functionally distinct mGluR subtypes are localized 
to specific neuron types at presynaptic and postsynaptic membranes, their physiological functions involving the generation of slow excitatory and inhibitory synaptic potentials, modulation of synaptic transmission, synaptic integration, and plasticity.

As with iGluRs, the mGluRs are classified into 4 groups (Group I - IV) based on AA sequence similarities, agonist pharmacology and the signal transduction pathways to which they are coupled ${ }^{240}$. Each receptor is formed from the co-assembly of several subunits ${ }^{239,240,363}$. To date, eight subunits (named mGluR1 through mGluR8) have been cloned $^{239,260,262-267}$

Briefly, Group I (mGluR 1, 5, and 6) stimulates inositol phosphate metabolism and mobilization of intracellular $\mathrm{Ca}^{++}$, Group II (mGluR 2 and 3 ) and Group III (mGluR 4, 68 ) are coupled to adenylcyclase $22,25,33,56$, and Group IV is coupled to the activation of phospholipase D (PLD) ${ }^{368}$. The latter class is more efficiently activated by L-cysteinesulfonic acid (L-CSA) rather than Glu, which suggests that L-CSA may serve as an endogenous agonist of this receptor $^{55}$.

As with the iGluRs, the mGluRs also have a unique distribution in the CNS and retina, which reflects a diversity of function in normal and pathological processes. The mGluRs have certain features that distinguish them from the iGluRs. First, the mGluRs modulate the activity of neurons rather than mediate fast synaptic neurotransmission. Second, the distribution of the mGluRs is highly diverse and heterogeneous. Different subclasses are localized uniquely at both the anatomical and cellular levels. For example, mGluR 2 and 3 are found in high density in the cerebral cortex, whereas mGluR 4 is found in high density in the thalamus but not in the cortex and mGluR 6 is almost exclusively found in the retina.

Activation of mGluRs alters local transmitter release and behaviors of experimental animals. In particular, mGluRs regulate phosphorylation of several key signaling proteins, including protein kinases and transcription factors, resulting in significant changes in immediate early gene and neuropeptide gene expression in striatal neurons. The prominent involvement of mGluRs in genomic responses to synaptic stimulation is considered to play a pivotal role in the development of synaptic and neuronal plasticity underlying long-term adaptive changes in cellular physiology related to a variety of neurological disorders. mGluR also regulates dopamine transmission, an important factor in many neurological disorders ${ }^{369}$.

Motor neuron activity changes significantly after administration of mGluR antagonists. Antagonists for Group II and for Group III mGluR enhance synaptic currents in rat spinal lumbar and cervical motor neurons ${ }^{370-372}$. This increased current is presumably caused by the blockade of presynaptic receptors, suggesting that endogenous activation of these receptors attenuates synaptic transmission. In phrenic motor neurons, the Group I mGluR antagonist (R,S)1-aminoindan-1,5,dicarboxylic acid (AIDCA) significantly reduces excitatory postsynaptic currents amplitude,

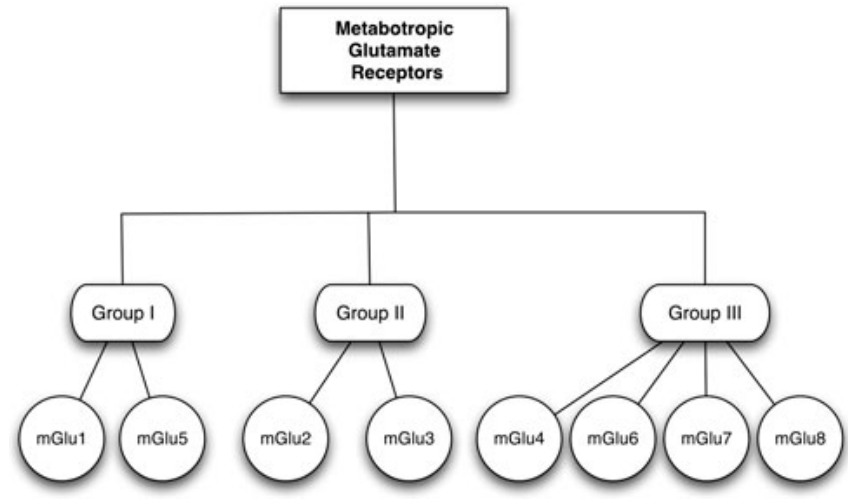

Fig. 8. The relationship of metabotropic glutamate receptors to one another

suggesting that postsynaptic Group I mGluR, along with various ionotropic receptors ${ }^{373,374}$, are activated by endogenously released Glu during inspiration. Three groups of mGluR are functionally expressed in motor neurons to mediate differential effects on intrinsic and synaptic properties via distinct mechanisms operating at pre- or postsynaptic sites. The diversity of actions mediated by various receptor subtypes provides a wide dynamic range for modulation of motor neuron excitability.

\section{The glutamate system: agonists and antagonists}

1) iGluRs and mGluRs

As Glu, GluR, and GluTP are ubiquitous and have a plethora of effects, antagonists to GluR are under evaluation for a number of diseases. So far most efforts have been directed toward antagonism to the iGluR, but some effects have also been made with respect to the mGluR. Glu, NMDA, AMPA and Ka are the most commonly used GluR agonists. The purpose of developing antagonists is two fold: to enable investigation into the mechanism of action of the GluR and to hopefully develop new drugs targeting diseases know to have basis in altered Glu activity ${ }^{47}$. A summary of a sample of the GluR agonists and antagonists available can be seen in Table 7 .

The side effects of agonist over stimulation have been previously discussed under the section on excitatory amino acids (EAAs). Antagonists, which completely block NMDA receptors, cause numerous side effects such as memory impairment, psychomimetic effects, ataxia and motor incoordination as they impair normal synaptic transmission $^{375}$.

\section{2) Glycine}

Most full glycineB antagonists, without intrinsic partial agonist activity, show very poor penetration to the CNS, although some agents with improved, but by no means optimal pharmacokinetic properties, have now been developed. Glycine $\mathrm{B}_{\mathrm{B}}$ antagonists have been reported to lack many of the side effects classically associated with NMDA receptor blockade such as no neurodegenerative changes in the cingulate and retrosplenial cortex even after high 
Table 6. Metabotropic Glutamate Receptors Function and Structure

\begin{tabular}{|l|l|c|l|}
\hline Receptor & \multicolumn{1}{|c|}{ Function } & Molecular structure & \multicolumn{1}{c|}{ Other actions } \\
\hline mGlu & $\begin{array}{l}\text { Activation of many of these receptors } \\
\text { leads to inhibition of postsynaptic } \\
\mathrm{Ca}^{++} \text {and } \mathrm{Na}^{+} \text {channels. }\end{array}$ & G protein $\mathrm{G}_{\mathrm{q} / 11}$ or $\mathrm{G}_{\mathrm{i} / \mathrm{o}}$ & $\begin{array}{l}\text { Unlike the excitatory ionotropic glutamate receptors, the } \\
\text { metabotropic receptors cause slower responses that can either } \\
\text { increase or decrease the excitability of the postsynaptic neuron. }\end{array}$ \\
\hline
\end{tabular}

Table 7. Summary of Selective iGlu and mGlu Ligands

\begin{tabular}{|c|c|c|c|}
\hline \multicolumn{4}{|c|}{ Ionotropic (iGlu) receptors } \\
\hline Receptor type & NMDA & AMPA & Kainate \\
\hline Agonists & NMDA; Tetrazolylglicene & $\begin{array}{l}\text { AMPA; LY } 404187 ;(\mathrm{S})-5 \text { - } \\
\text { fluorowillardiine }\end{array}$ & $\begin{array}{l}\text { Kainate; ATPA; (S)-5-iodowillardiine; } \\
\text { LY339434; SYM } 2081\end{array}$ \\
\hline Antagonists & $\begin{array}{l}\text { CPP (selective NR2A/NR2B vs. NR2C/ } \\
\text { NR2D); PEAQX (selective NR2A vs. NR2B); } \\
\text { Ro-25-6981; (NR2B selective }\end{array}$ & $\begin{array}{l}\text { NBQX; LY293558; (S)-ATPO; } \\
\text { GYKI53655 }\end{array}$ & LY382884; UBP302; NS 3763 \\
\hline \multicolumn{4}{|c|}{ Metabotropic (mGlu) receptor ligands } \\
\hline Receptor type & Group I & Group II & Group III \\
\hline Agonists & $\begin{array}{l}\text { (S)-DHPG; CHPG (mGlu 5); (3S,2R)-ACPD; } \\
\text { Ro (+) 01-6128 (mGlu1); (-) DFB (mGlu 5); } \\
\text { CBPG (mGlu5) }\end{array}$ & $\begin{array}{l}\text { LY354740; LY487379; CCG-1; } \\
\text { APDC. }\end{array}$ & $\begin{array}{l}\text { LY379268; (S)-AP4; DCPG (mGlu 8); } \\
\text { (+)PHCC (mGlu4); CCG-1; (L)-AP4; } \\
\text { PPG. }\end{array}$ \\
\hline Antagonists & $\begin{array}{l}\text { LY367385 (mGlu1); (S)-MCPG; (-)MPEP; } \\
\text { (mGlu5); (-)MTEP (mGlu5); (-) CPCOEt } \\
\text { (mGlu1); (-)BAY36-7620 (mGlu) }\end{array}$ & LY341495; EGLU & CPPG; UBP1112 \\
\hline
\end{tabular}

$\operatorname{doses}^{376}$ and no psychomimetic-like or learning impairing effects at anticonvulsive doses ${ }^{237,377-380}$. The improved neuroprotective therapeutic profile of glycine ${ }_{B}$ full antagonists could be due to their ability to reveal glycinesensitive desensitization ${ }^{381}$.

Kynurenic acid is an endogenous glycine ${ }_{\mathrm{B}}$ antagonist but it seems unlikely that concentrations are sufficient to interact with NMDA receptors under normal conditions $^{237,382}$. However, concentrations are raised under certain pathological conditions ${ }^{237,382}$ and interactions with other receptors such as $\alpha 7$ neuronal nicotinic have been reported at lower concentrations ${ }^{237,382,383}$.

D-cycloserine and (+R)-HA-966 are partial agonists at the glycine B $_{\mathrm{B}}$ site with different levels of intrinsic activity of $57 \%$ and $14 \%$ respectively in cultured hippocampal neurons ${ }^{384}$. Although these systemically active partial agonists do not induce receptor desensitization ${ }^{384-386}$, they have favorable therapeutic profiles in some in vivo models ${ }^{387,388}$. In part this positive effect may be due to their own intrinsic activity as agonists at the glycine ${ }_{B}$ site, which would serve to preserve a certain level of NMDA receptor function even at very high concentrations ${ }^{389-391}$.

Although ACPC has been reported to be a partial agonist with very high intrinsic activity, it is probably really a full agonist at the glycine ${ }_{\mathrm{B}}$ site and actually behaves as an antagonist in some in vivo models, resulting in neuroprotection and anticonvulsive effects, which are likely to be mediated via competitive antagonistic properties at higher concentrations ${ }^{392}$. The consistent observation that chronic treatment with ACPC is neuroprotective could be because it desensitizes or uncouples NMDA receptors ${ }^{393,394}$ or may be related to an increase in the relative levels of NR2C expression ${ }^{390}$.

\section{Dose-response}

D-cycloserine shows agonist like features at low doses, while with increasing dosing antagonistic effects predominate $^{387}$. Such findings are often falsely interpreted to be "typical" for partial agonists: agonism at low and antagonism at high doses. However, partial agonism actually means that an agent reaches a ceiling, non-maximal effect at higher doses. That is its intrinsic activity is limited compared with a full agonist, so that it will antagonize receptor activation at high concentrations but facilitate at low concentrations ${ }^{384,385}$.

The consistent biphasic effects of D-cycloserine seen in vivo may be related to different affinities and intrinsic activities at NMDA receptor subtypes. D-cycloserine is a partial agonist for the murine equivalents of NR1/2A and NR $1 / 2 \mathrm{~B}$ heteromers [ $38 \%$ and $56 \%$ intrinsic activity compared to Gly $10 \mu \mathrm{M}$ ] but is more effective than Gly at NR1/2C $(130 \%)^{395}$. This effect is accompanied by higher affinity at NR1/2C receptors - NR1/2C $>\mathrm{NR} 1 / 2 \mathrm{D}>>\mathrm{NR} 1 /$ $2 \mathrm{~B}>\mathrm{NR} 1 / 2 \mathrm{~A}^{395}$. In contrast, similar data showed that the intrinsic activity at NR1/2C was even higher $(192 \%)^{396}$. Therefore, it is likely that the biphasic effects seen in vivo are due to agonistic actions at NR1/2C receptors at lower doses and inhibition of NR1/2A and NR1/2B containing receptors at higher doses.

In conclusion, the glutamate system is central to many 
neurotransmission processes, and this review has attempted to summarize some aspects of the complex glutamate system. As we learn more regarding this system, it is probable that current and future development of agonists and antagonists for treatment of a number of diseases will occur. The second part of this review will address the pathophysiology and pathology of the GluRs.

\section{References}

1. Sabbatini RME. Neurons and synapses. Brain and Mind. 17: 1-6. 2003.

2. Florey E. An inhibitory and an excitatory factor of mammalian central nervous system, and their action on a single sensory neuron. Arch Int Physiol. 62: 33-53. 1954.

3. Kuffler SW. Mechanisms of activation and motor control of stretch receptors in lobster and crayfish. J Neurophysiol. 17: 558-574. 1954.

4. Nicoll RA and Malenka RC. Contrasting properties of two forms of long-term potentiation in the hippocampus. Nature. 377: 115-118. 1995.

5. Scallet AC, Schmued LC, and Johannessen JN. Neurohistochemical biomarkers of marine neurotoxicant, domoic acid. Neurotoxicol Teratol. 27: 745-752. 2005.

6. Bowery $\mathrm{NG}$ and Smart TG. GABA and glycine as neurotransmitters: a brief history. Br J Pharmacol. 147: S109-S119. 2006.

7. Bliss TVP and Collingridge GL. A synaptic model of memory: Long-term potentiation in the hippocampus. Nature. 361: 31-39. 1993.

9. Chapman PF, Kairiss EW, Keenan CL, and Brown TH. Long-term synaptic potentiation in the amygdala. Synapse. 6: 271-278. 1990.

10. Bruno V, Copani A, Battagli G, Raffaele R, Shinozaki H, and Nicoletti F. Protective effect of the metabotropic glutamate receptor agonist, DCG-IV, against excitotoxic neuronal death. Eur J Pharmacol. 256: 109-112. 1994.

11. Masu M, Tanabe Y, Tsuchida K, Shigemoto R, and Nakanishi S. Sequence and expression of a metabotropic glutamate receptor. Nature. 349: 760-765. 1991.

12. Meir A, Ginsberg S, Butkevich A, Kachalasky SG, Kaiserman I, Ahdut R, Demirgoren S, and Rahamimoff R. Ion channels in presynaptic nerve terminals and control of transmitter release. Physiol Rev. 79: 1019-1088. 1999.

13. Raiteri M. Functional pharmacology in human brain. Pharmacol Rev. 58: 162-193. 2006.

14. Watkins JC and Jane DE. The glutamate story. Br J Pharmacol. 147 (Suppl 1): S100-108. 2006.

15. Gronier B and Debonnel G. Involvement of sigma receptors in the modulation of the glutamatergic/NMDA neurotransmission in the dopaminergic systems. Eur J Pharmacol. 368: 183-196. 1999.

16. Guitart X, Méndez R, Ovalle S, Andreu F, Carceller A, Farré AJ, and Zamanillo D. Regulation of ionotropic glutamate receptor subunits in different rat brain areas by a preferential sigma(1) receptor ligand and potential atypical antipsychotic. Neuropsychopharmacology. 23: 539-546. 2000.

17. Bermack JE and Debonnel G. The role of sigma receptors in depression. J Pharmacol Sci. 97: 317-336. 2005.

18. Dong J, Bloom JD, Goncharov V, Chattopadhyay M,
Millhauser GL, Lynn DG, Scheibel T, and Lindquist S. Probing the role of PrP repeats in conformational conversion and amyloid assembly of chimeric yeast prions. J Biol Chem. 282: 34204-34212. 2007.

19. Chittajallu R, Vignes M, Dev KK, Barnes JM, Collingridge GL, and Henley JM. Regulation of glutamate release by presynaptic kainate receptors in the hippocampus. Nature. 379: 78-81. 1996.

20. Swanson CJ, Bures M, Johnson MP, Linden AM, Monn JA and Schoepp DD. Metabotropic glutamate receptors as novel targets for anxiety and stress disorders. Nat Rev Drug Discov. 4: 131-144. 2005.

21. Dingledine R, Borges K, Bowie D, and Traynelis SF. The glutamate receptor ion channels. Pharmacol Rev. 51: 7-61. 1999.

22. Dingledine $\mathrm{R}$ and McBain CJ. Excitatory amino acids transmitters. In: Basic Neurochemistry. GJ Siegal, RW Agronoff, BW Albers and PB Molinof (eds). Raven Press, New York. 367-387. 1994.

23. Mueller R, Gill S, and Pulido O. The monkey (Macaca fascicularis) heart neural structures and conducting system: an immunochemical study of selected neural biomarkers and glutamate receptors. Toxicol Pathol. 31: 227-234. 2003.

24. Gasic GP and Hollmann M. Molecular neurobiology of glutamate receptors. Ann Rev Physiol. 54: 507-536. 1992.

25. Hollmann $\mathrm{M}$ and Heinemann $\mathrm{S}$. Cloned glutamate receptors. Annu Rev Neurosci. 17: 31-108. 1994.

26. Asztely $F$ and Gustafasson B. Ionotropic glutamate receptors: Their possible role in the expression of hippocampal synaptic plasticity. Mol Neurobiol. 12: 1-11. 1996.

27. Lipton SA. Prospects for clinically tolerated NMDA antagonists: Open-channel blockers and alternative redox states of nitric oxide. Trends Neuorsci. 16: 527-532. 1993.

28. Lipton SA and Gendelman HE. Dementia associated with the acquired immunodeficiency syndrome. N Engl J Med. 332: 934-940. 1995.

29. Lipton SA and Rosenberg PA. Excitatory amino acids as a final common pathway for neurologic disorders. N Engl $\mathrm{J}$ Med. 330: 613-622. 1994.

30. Meldrum BS. The role of glutamate in epilepsy and other central nervous disorders. Neurology. 44: 14-23. 1994.

31. Miller S, Kesslak JP, Romano C, and Cotman CW. Roles of metabotropic receptors in brain plasticity and pathology. Ann NY Acad Sci. 757: 460-474. 1996.

32. Miller HP, Levey AI, Rothstein JD, Tzingounis AV, and Conn PJ. Alterations in glutamate transporter protein levels in kindling-induced epilepsy. J Neurochem. 68: 1564-1570. 1997.

33. Ozawa S, Kamiya H, and Tsuzuki K. Glutamate receptors in the mammalian central nervous system. Prog Neurobiol. 54: 581-618. 1998.

34. Schoepp DD. Novel function for subtypes of metabotropic glutamate receptors. Neurochem Int. 24: 439-449. 1994.

35. Choi DW. Excitotoxic cell death. J Neurobiol. 23: 12611276. 1992.

36. Ozono R, O'Connell DP, Vaughan C, Botkin SJ, Walk SF, Felder RA, and Carey RM. Expression of the subtype 1A dopamine receptor in the rat heart. Hypertension. 27: 693703. 1996.

37. Ankarcrona M, Dypbukt JM, Bonfoco E, Zhivotovsky B, 
Orrenius S, Lipton SA, and Nicotera P. Glutamate induced neuronal death: a succession of necrosis or apoptosis depending on mitochondrial function. Neuron. 15: 961973. 1995.

38. Lipton SA and Nicotera P. Calcium, free radicals and excitotoxins in neuronal apoptosis. Cell Calcium. 223: 165171. 1998.

39. Nijjar MS and Nijjar SS. Domoic acid-induced neurodegeneration resulting in memory loss is mediated by $\mathrm{Ca}^{2+}$ overload and inhibition of $\mathrm{Ca}^{2++}$ calmodulinstimulated adenylate cyclase in rat brain (review). Int J Mol Med. 6: 377-389. 2000.

40. Rosin C, Bates TE, and Skaper SD. Excitatory amino acid induced oligdendrocyte death in vitro: receptor-dependent and -independent mechanisms. J Neurochem. 90: 11731185. 2004.

41. Truong DD, Bhidayasiri R, and Wolters E. Management of non-motor symptoms in advanced Parkinson disease. J Neurol Sci. 266: 216-218. 2008.

42. Underhill SM and Goldberg MP. Hypoxic injury of isolated axons is dependent of ionotropic glutamate recptors. Neurobiol Dis. 25: 284-290. 2007.

43. Bruni JE, Bose R, Pinsky C, and GavinG. Circumventricular organ origin of domoic acid-induced neuropathology and toxicology. Brain Res Bull. 26: 419424. 1991.

44. Price MT, Olney JW, and Cicero TJ. Acute elevations of serum luteinizing hormone induced by kainic acid, Nmethyl aspartic acid, or homocysteic acid. Neuroendocrinol. 26: 352-358. 1978.

45. Smith QR. Transport of glutamate and other amino acids at the blood brain barrier. J Nutr. 130: 1016S-1022S. 2000.

46. Choi DW. Glutamte neurotoxicity and diseases of the nervous system. Neuron. 1: 623-634. 1988.

47. Meldrum BS. Glutamate as a neurotransmitter in the brain: review of physiology and pathology. J Nutr. 130: 1007S1015S. 2000.

48. Gill SS and Pulido OM. Glutamate receptors in peripheral tissues: current knowledge, future research, and implications for toxicology. Toxicol Pathol. 29: 208-223. 2001.

49. Obrenovitch TP and Urenjak J. Altered glutamatergic transmission in neurological disorders: From high extracellular glutamate to excessive synaptic efficacy. Prog Neurobiol. 51: 39-87. 1997.

50. Parsons CG, Danysz W, and Quack G. Glutamate in CNS Disorders as a target for drug development. An update. Drug News Perspect. 11: 523-569. 1998.

51. Singh P, Mann KA, Mangat HK, and Kaur G. Prolonged glutamate excitotoxicity: effects on mitochondrial antioxidants and antioxidant enzymes. Mol Cell Chem. 234: 139-145. 2003.

52. Boldyrev A, Bulygina E, Makhro A. Glutamate receptors modulate oxidative stress in neuronal cells. Neurotox Res. 6: 581-587. 2004.

53. South J. Tired of being tired? Anti-Aging Bull. 4: 3-21. 1999.

54. Li S and Stys PK. Mechanisms of ionotropic glutamate receptor-mediated excitottoxicity in isolated spinal cord white matter. J Neurosci. 20: 1190-1198. 2000.

55. Conn PJ and Pin JP. Pharmacology and functions of metabotrophic receptors. Ann Rev Pharmacol Toxicol. 37:
205-237. 1997.

56. Cunningham MD, Ferkany JW, and Enna SJ. Excitatory amino acid receptors: A gallery of new targets for pharmacological intervention. Life Sci. 54: 135-148. 1994.

57. Ozawa $\mathrm{S}$ and Rossier J. Molecular basis for functional differences of AMPA-subtype glutamate receptors. News Physiol Soc. 11: 77-82. 1996.

58. Rothman SM and Olney JW. Excitotoxicity and the NMDA receptor. Trends Neurosci. 10: 299-302. 1987.

59. Choi DW. Calcium: still center-stage in hypoxic-ischemic neuronal death. Trends Neurosci. 18: 58-60. 1995.

60. Gill SS, Mueller RW, McGuire PR, and Pulido OM. Potential target sites in peripheral tissues for excitatory neurotransmission and excitotoxicity. Toxicol Pathol. 28: 277-284. 2000.

61. Skerry TM and Genever PG. Glutamate signalling in nonneuronal tissues. Trends Pharmacol Sci. 4: 174-181. 2001.

62. Meldrum BS. Amino acids as dietary excitotoxins: a contribution to understanding neurodegenerative disorders. Brain Res Rev. 18: 293-314. 1993.

63. Iverson F, Truelove J, Tryphonas L, and Nera EA. The toxicology of domoic acid administered systemically to rodents and primates. Can Dis Wkly Rep. 16 (Suppl 1E): 15-8; 18-19. 1990

64. Krogsgaard-Larsen P and Hansen JJ. Naturally-occurring excitatory amino acids as neurotoxins and leads in drug design. Toxicol Lett. 64-65: 409-416. 1992.

65. Peng YG, Taylor TB, Finch RE, Switzer RC, and Ramsdell JS. Neuroexcitatory and neurotoxic actions of the amnesic shellfish poison, domoic acid. Neuroreport. 5: 981-985. 1994.

66. Perl TM, Bédard L, Kosatsky T, Hockin JC, Todd EC, McNutt LA, and Remis RS. Amnesic shellfish poisoning: a new clinical syndrome due to domoic acid. Can Dis Wkly Rep. 16 (Suppl 1E): 7-8. 1990.

67. Truelove J, Mueller R, Pulido O, and Iverson F. Subchronic toxicity study of domoic acid in the rat. Food Chem Toxicol. 34: 525-529. 1996.

68. Sureda F, Copani A, Bruno V, Knopel T, Meltzger G, and Nicoletti F. Metabotropic glutamate receptor agonists stimulate polyphosphoinositide hydrolysis in primary cultures of rat hepatocytes. Eur J Pharmacol. 338: R1-R2. 1997.

69. Teitelbaum J, Zatorre RS, Carpenter S, Gendron D, Evans AC, Gjedde A, and Cashman NR. Neurologic sequelae of domoic acid intoxication due to the ingestion of contaminated mussels. N Engl J Med. 322: 1781-1787. 1990.

70. Tryphonas L, Truelove J, Iverson F, Todd ECD, and Nera EA. Neuropathology of experimental domoic acid poisoning in non-human primates and rats. Can Dis Wkly Rep. 16 (Suppl 1E): 75-81. 1990.

71. Chandrasekaran A, Ponnambalam G, and Kaur C. Domoic acid-induced neurotoxicity in the hypocampus of adult rats. Neurotox Res. 6: 105-117. 2004.

72. Zautcke JL, Schwartz JA, and Mueller EJ. Chinese restaurant syndrome: A review. Ann Emerg Med. 15: 1210 1213. 1986.

73. Silvagni PA, Lowenstine LJ, Spraker T, Lipscomb TP and Gulland FMD. Pathology of domoic acid toxicity in California sea lions (Zalophus californianus). Vet Pathol. 42: 184-191. 2005. 
74. Danysz W, Parsons CG, Bresink I, and Quack G. Glutamate in CNS disorders - A revived target for drug development. Drug News Perspect. 8: 261-277. 1995.

75. Beal MF. Does impairment of energy metabolism result in excitotoxic neuronal death in neurodegenerative illnesses? Ann Neurol. 31: 119-130. 1992.

76. Beal MF. Aging, energy, and oxidative stress in neurodegenerative diseases. Ann Neurol. 38: 357-366. 1995.

77. Beal MF. Excitotoxicity and nitric oxide in Parkinson's disease pathogenesis. Ann Neurol. 44 (Suppl 1): S110S114. 1998.

78. Blaylock R. Excitotoxins. Santa Fe: Health Press, 1997.

79. Blaylock RL. Excitotoxicity: a possible central mechanism in fluoride neurotoxicity. Fluoride. 37: 301-314. 2004.

80. Starr MS. Antiparkinsonian actions of glutamate antagonists - alone and with 1-DOPA: a review of evidence and suggestions for possible mechanisms. J Neural TransmParkinsons. 10: 141-185. 1995.

81. Plaitakis A, Fesdjian CO, and Shashidharan P. Glutamate antagonists in amyotrophic lateral sclerosis: a review of their therapeutic potential. CNS Drugs. 5: 437-456. 1996.

82. Shaw PJ and Ince PG. Glutamate, excitotoxicity and amyotrophic lateral sclerosis. J Neurol. 244: S3-S14. 1997.

83. Trujillo KA and Akil H. Excitatory amino acids and drugs of abuse: A role for N-methyl-D-aspartate receptors in drug tolerance, sensitization and physical dependence. Drug Alcohol Depend. 38: 139-154. 1995.

84. Dickenson A. Mechanisms of central hypersensitivity: Excitatory amino acid mechanisms and their control. In: Pharmacology of Pain, A Dickenson and JM Besson (eds). Springer-Verlag, Berlin. 167-210. 1997.

85. Sanabria ER, Pereira MF, Dolnikoff MS, Andrade IS, Ferreira AT, Cavalheiro EA, and Fernandes MJ. Defficit in hypocampal long-term potentiation in monosodium glutamate-treated rats. Brain Res Bull. 59: 47-51. 2002.

86. Freeman M. Reconsiderating the effects of monosodium glutamate: a literature review. J Amer Acad Nurse Pract. 18: $482-486.2006$

87. Massey SC. Cell types using glutamate as a neurotransmitter in the vertebrate retina. Progr Retinal Res. 9: 399-425. 1990.

88. Erulkar SD. Chemically mediated synaptic transmission: an overview. In: Basic Neurochemistry, $5^{\text {th }}$ ed. GJ Siegel, BJ Agranoff, RW Albers, and PB Molinoff (eds). Raven Press, New York. 181-208. 1994.

89. Young VR and Ajami AM. Glutamate: An Amino acid of particular distinction. J Nutr. 130: 892S-900S. 2000.

90. Collingridge GL and Singer W. Excitatory amino acid receptors and synaptic plasticity. Trends Pharmacol Sci. 11: 290-296. 1990.

91. Collingridge GL and Bliss TVP. Memories of NMDA receptors and LTP. Trends Neurosci. 18: 54-56. 1995.

92. Fitsanakis VA and Aschner M. The importance of glutamate, glycine, and gamma-aminobutyric acid and regulation in manganese, mercury, and lead neurotoxicity. Toxicol Appl Pharmacol. 204: 343-354. 2005.

93. Baker DA, Xi ZX, Shen H, Swanson CJ, and Kalivas PW. The origin and neuronal function of in vivo nonsynaptic glutamate. J Neurosci. 22: 9134-9141. 2002.

94. Blakely RD, Robinson MB, Guarda AS, and Coyle JT. A re-examination of the interaction of N-acetyl-L-aspartyl-L- glutamate with a subpopulation of rat brain membrane L$[3 \mathrm{H}]$ glutamate binding sites. Eur J Pharmacol. 151: 419426. 1988 .

95. Nicholls D. Amino acids as neurotransmitters. In: Proteins, Transmitters and Synapses. D Nicholls (ed). Blackwell Science, Cambridge. 155-185. 1994.

96. Jackson PF and Slusher BS. Design of NAALAdase inhibitors: a novel neuroprotective strategy. Curr Med Chem. 8: 949-957. 2001.

97. Danbolt NC. Glutamate uptake. Prog Neurobiol. 65: 1-105. 2001.

98. Butcher SP, Sandberg M, Hagberg H, and Hamberger A. Cellular origins of endogenous amino acids released into the extracellular fluid of the rat striatum during severe insulin-induced hypoglycemia. J Neurochem. 48: 722-723. 1987.

99. Rockhold RW, Acuff CG, and Clower BR. Excitotoxininduced myocardial necrosis. Eur J Pharmacol. 166: 571576. 1989.

100. Watters MR. Organic neurotoxins in seafoods. Clin Neurol Neurosurg. 97: 119-124. 1995.

101. Winter CR and Baker RC. L-Glutamate induced changes in intracellular calcium oscillation frequency through nonclassical glutamate receptor binding in cultured rat myocardial cells. Life Sci. 57: 1925-1934. 1996.

102. Erdö SL. Excitatory amino acid receptors in the mammalian periphery. Trends Pharmacol Sci. 12: 426-429. 1991.

103. Olney JW. Glutamate, a neurotoxic transmitter. J Child Neurol. 4: 218-26. 1989.

104. Olney JW. Excitotoxins in foods. NeuroToxicology. 15: 535-544. 1994.

105. Marc RE, Liu W-LS, Kalloniatis M, Raiguel SF, and Van Haesendonck E. Patterns of glutamate immunoreactivity in the goldfish retina. J Neurosci. 10: 4006-4034. 1990.

106. Aizenman E, Frosch MP, and Lipton SA. Responses mediated by excitatory amino acid receptors in solitary retinal ganglion cells from rat. J Physiol. 396: 75-91. 1988.

107. Zhou ZJ, Fain GL, and Dowling JE. The excitatory and inhibitory amino acid receptors on horizontal cells isolated from the white perch retina. J Neurophysiol. 70: 8-19. 1993.

108. Sasaki T and Kaneko A. L-glutamate-induced responses in OFF-type bipolar cells of the cat retina. Vision Res. 36: 787-795. 1996.

109. Yudkoff M, Daikhin Y, Nissim I, Horyn O, Lazarow A, Luhovyy B, Wehrli S, and Nissim I. Response of brain amino acid metabolism to ketosis. Neurochem Int. 47: 119 128. 2005.

110. Watford M. Glutamine and glutamate metabolism across the liver sinusoid. J Nutr. 130: 983S-987S. 2000.

111. Reeds PJ, Burrin DG, Stoll B, and Jahoor F. Intestinal glutamate metabolism. J Nutr. 130: 978S-982S. 2000.

112. Brosnan JT. Glutamate, at the interface between amino acid and carbohydrate metabolism J Nutr. 130: 988S-990S. 2000.

113. Munro HN. Factors in the regulation of glutamate metabolism: In: Glutamic Acid: Advances in Biochemistry. LJ Filer, S Garattini, MR Kare, WA Reynolds and RJ Wurtman (eds). Raven Press, New York. 55-68. 1979.

114. Garattini S. Glutamic acid, twenty years later. J Nutr. 130: 901S-909S. 2000.

115. Oliet SH, Piet R, and Poulain DA. Control of glutamate 
clearance and synaptic efficacy by glial coverage of neurons. Science. 292: 923-926. 2001.

116. Jahr CE and Lester RA. Synaptic excitation mediated by glutamate-gated ion channels. Curr Opin Neurobiol. 2: 270274. 1992.

117. Arriza JL, Fairman WA, Wadiche JI, Murdoch GH, Kavanaugh MP, and Amara SG. Functional comparisons of three glutamate transporter subtypes cloned from human motor cortex. J Neurosci. 14: 5559-5569. 1994.

118. Malandro MS and Kilberg MS. Molecular biology of mammalian amino acid transporters. Annu Rev Biochem. 65: 305-336. 1996.

119. Bai Y, Hájek P, Chomyn A, Chan E, Seo BB, MatsunoYagi A, Yagi T, and Attardi G. Lack of complex I activity in human cells carrying a mutation in MtDNA-encoded ND4 subunit is corrected by the Saccharomyces cerevisiae NADH-quinone oxidoreductase (NDI1) gene. Biol Chem. 276: 38808-38813. 2001.

120. Moriyama Y and Yamamoto A. Glutamatergic chemical transmission: Look! Here, there, and anywhere. J Biochem (Tokyo). 135: 155-163. 2004.

121. Bode BP. Recent molecular advances in mammalian glutamine transport. J Nutr. 131: 2475S-2485S. 2000

122. Gill SS and Pulido OM. Glutamate receptors in peripheral tissues: excitatory transmission outside of the CNS. Kluwer Academic/Plenum Publishers. New York. 2005.

123. Wantanabe M, Mishina M, and Inoue Y. Distinct gene expression of the $\mathrm{N}$-methyl-D-aspartate receptor channel subunit in peripheral neurons of the mouse sensory ganglia and adrenal gland. Neurosci Lett. 165: 183-186. 1994.

124. Aas P, Tanso R, and Fonnum F. Stimulation of peripheral cholinergic nerves by glutamate indicates a new peripheral GluR. Eur J Pharmacol. 164: 93-102. 1989.

125. Coggeshall RE and Carlton SM. Ultrastructural analysis of NMDA, AMPA, and kainate receptors on myelinated and unmyelinated axons in the periphery. J Comp Neuro. 391: 78-86. 1998.

126. Demenes D, Lleixa A, and Dechesne CJ. Cellular and subcellular localization of AMPA-selective glutamate receptors in the mammalian peripheral vestibular system. Brain Res. 671: 83-94. 1995.

127. Sasa M, Takeshita S, Amano T, and Kutisu K. Primary neurotransmitters and regulatory substances onto vestibular nucleus neurons. Biol Sci Space. 15: 371-374. 2001.

128. Marc RE and Lam DMK. Uptake of aspartic and glutamic acid by photoreceptors in goldfish retina. Proc Natl Acad Sci. 78: 7185-7189. 1981

129. Tachibana $M$ and Kaneko A. L-glutamate-induced depolarization in solitary photoreceptors: a process that may contribute to the interaction between photoreceptors in situ. Proc Natl Acad Sci. 85: 5315-5319. 1988.

130. Eliasof S and Werblin F. Characterization of the glutamate transporter in retinal cones of the tiger salamander. J Neurosci. 13: 402-411. 1993.

131. Yang X-L and $\mathrm{Wu}$ SM. Coexistence and function of glutamate receptor subtypes in the horizontal cells of the tiger salamander retina. Vis Neurosci. 7: 377-382. 1991.

132. Yang $\mathrm{JH}$ and $\mathrm{Wu} \mathrm{SM}$. Characterization of glutamate transporter function in the tiger salamander retina. Vision Res. 37: 827-838. 1997.

133. Yamaguchi I, Jose PA, Mouradian M, Canessa LM, Monsma FJ, Sibley DR, Takeyasu K, and Felder RA.
Expression of dopamine D1A receptor in proximal tubule of rat kidneys. Am J Physiol. 264: F280-F285. 1993.

134. Kiyama H, Sato K, and Tohyama M. Characteristic localization of non-NMDA type glutamate receptor subunits in the rat pituitary gland. Mol Br Res. 19: 262-268. 1993.

135. Mick G. Non- $N$-methyl-D-aspartate glutamate receptors in glial cells and neurons of the pineal gland in a higher primate. Neuroendocrinology. 61: 256-264. 1995.

136. Barb CR, Campbell RM, Armstrong JD, and Cox NM. Aspartate and glutamate modulation of growth hormone secretion in the pig: Possible site of action. Domestic Animal Endocrinol. 13: 81-90. 1996.

137. Bertrand G, Gross R, Puech R, Loubatieres-Mariana MM, and Bockaert J. Evidence for a glutamate receptor of the AMPA subtype which mediates insulin release from rat perfused pancreas. Br J Pharmacol. 106: 354-359. 1992.

138. Bertrand G, Gross R, Puech R, Loubatieres-Mariana MM, and Bockaert J. Glutamate stimulates glucagon secretion via an excitatory amino acid receptor of the AMPA subtype in rat pancreas. Br J Pharmacol. 237: 45-50. 1993.

139. Gonoi T, Mizuno N, Inagaki N, Kuromi H, Seino Y, Miyazaki J, and Seino S. Functional neuronal ionotropic glutamate receptors are expressed in the non-neuronal cell line MIN6. J Biol Chem. 269: 16989-16992. 1994.

140. Hardy M, Younkin D, Tang CM, Pleasure J, Shi QY, Williams M, and Pleasure D. Expression of non-NMDA glutamate receptor channel genes by clonal human neurons. J Neurochem. 63: 482-489. 1994.

141. Inagaki $\mathrm{N}$, Kuromi $\mathrm{H}$, Gonoi $\mathrm{T}$, Okamoto $\mathrm{Y}$, Ishida $\mathrm{H}$, Seino Y, Kaneko T, Iwanaga T and Seino S. Expression and role of ionotropic glutamate receptors in pancreatic islet cells. FASEB J. 9: 686-691. 1995.

142. Lindstrom $\mathrm{P}$ and Ohlsson L. Effects of $N$-Methyl-DLaspartate on isolated rat somatotrophs. Endocrinology. 131: 1903-1907. 1992.

143. Liu M-T, Rothstein JD, Gershon MD, and Kirchgessner F. Glutamatergic enteric neurons. J Neurosci. 17: 4764-4784. 1997.

144. Molnar E, Varadi A, McIlhinney RAJ, and Ashcroft SJH. Identification of functional ionotrophic glutamate receptor proteins in the pancreatic $\beta$ cells and in the islets of Langerhans. FEBS Lett. 371: 253-257. 1995.

145. Weaver CD, Yao TL, Powers AC, and Verdoorn TA. Differential expression of glutamate receptor subtypes in rat pancreatic islets. J Biol Chem. 271: 12977-12984. 1996.

146. Hayashi M, Morimoto R, Yamamoto A, and Moriyama Y. Expression and localization of vesicular glutamate transporters in pancreatic islets, upper gastrointestinal tract and testis. J. Histochem Cytochem. 51: 1375-1390. 2003.

147. Hayashi Y, Yamada H, Uehara S, Morimoto R, Muroyama A, Yatsushiro S, Takeda J, Yamamoto A, and Moriyama Y. Secretory granule-mediated co-secretion of L-Glutamate and glucagons triggers glutaminergic signal transmission in islets of Langerhans. J Bio Chem. 278: 1966-1974. 2003.

148. Pulido O, Veinot J, Mueller R, Kavanagh M, Rousseaux CG, and Gill, S. Toxicologic Pathology of Glutamate Receptors (GluRs) - An opportunity for pharmaceutical development. Part I - Human Heart. Cardiovascular Toxicologic Pathology: Safety Assessment and Risk Management, STP Annual General Meeting, Washington, DC June 2005. 
149. Chaudhari N, Yang H, Lamp C, Delay E, Cartford C, Than $\mathrm{T}$, and Roper S. The taste of monosodium glutamate: Membrane receptors in taste buds. J Neurosci. 16: 38173826. 1996

150. Hayashi Y, Zviman MM, Brand JG, Teeter JH, and Restrepo, D. Measurement of membrane potential and $[\mathrm{Ca} 2+]$ in cell ensembles: Application to the study of glutamate taste in mice. Biophys J. 71: 1057-1070. 1996.

151. Gill S, Veinot J, Kavanagh M, and Pulido O. Human heart glutamate receptors - implications for toxicology, food safety, and drug discovery. Toxicol Pathol. 35: 411-417. 2007.

152. Burns GA, Stephens KE, and Benson JA. Expression of mRNA for Nmethyl-D-aspartate (NMDAR 1) receptor by the enteric neurons of the rat. Neurosci Lett. 170: 87-90. 1994.

153. O'Connell DP, Aherne AM, Lane E, Felder RA, and Carey RM. Detection of dopamine receptors D1A subtype-species c mRNA in rat kidney by in situ hybridization. Am J Physiol. 275: F232-F241. 1998.

154. Stumer T, Amar M, Harvey RJ, Bermudez I, Minnen JV, and Darlison MG. Structure and pharmacological properties of a molluscan glutamategated cation channel and its likely role in the feeding behavior. J Neurosci. 16: 2869-2880. 1996.

155. Moroni F, Luzzi S, Micheli SF, and Zilleti L. The presence of $N$-methyl-D-aspartate type receptors for glutamic acid in the guinea pig myentericplexus. Neurosci Lett. 68: 57-62. 1986.

156. Shannon HE and Sawyer BD. Glutamate receptors of the Nmethyl-Daspartate subtype in the myentric plexus of the guinea pig ileum. J Pharmacol Exp Ther. 251: 518-523. 1989.

157. Sninsky CA, Brooderson RJ, Broome TA, and Bergeron RJ. Evidence for an $N$-methyl-D-aspartate (NMDA) receptor in the GI tract of guinea pigs: Studies with diethylhomospermine (DEHSPM). Gastroenterol. 106: A569. 1994.

158. Gill SS, Pulido OM, Mueller RW and McGuire PF. Molecular and immunochemical characterization of the ionotropic glutamate receptors in the rat heart. Brain Res Bull. 46: 429-434. 1998.

159. Genever PG, Wilkinson DJP, Patton AJ, Peet NM, Hong Y, Mathur A, Erusalimsky JD and Skerry TM. Expression of a functional N-methyl-Daspartate-type glutamate receptor by bone marrow megakaryocytes. Blood. 93: 2876-2883. 1999.

160. Haxhiu MA, Erokwu B, and Dreshaj IA. The role of excitatory amino acids in airway reflex responses in anaesthetized dogs. J Auton Nerv Sys. 67: 192-199. 1997.

161. Said SI. Glutamate receptors and asthmatic airway disease. Trends Biochem Sci. 20: 132-135. 1999.

162. Gill SS, Pulido OM, Mueller RW, and McGuire PF. Immunological characterization of the metabotrophic glutamate receptors in the rat heart. Brain Res Bull. 48: 143-146. 1999.

163. Morhenn VB, Waleh NS, Mansbridge JN, Unson D, Zolotorev A, Cline P, and Toll L. Evidence for an NMDA receptor subunit in human keratinocytes and rat cardiocytes. Eur J Pharmacol. 268: 409-414. 1994.

164. Pulido OM, Veinot J, Mueller R, Kavanagh M, Rousseaux CG, and Gill, S. Human heart glutamate receptors (GluRs)
- possible effector sites: An opportunity for drug discovery. Joint International Meeting of the Japanese Society of Toxicologic Pathology and the International Federation of Societies of Toxicologic Pathology, Kobe, Japan, February 2004.

165. Chenu C, Serre CM, Raynal C, Burt-Pichat B and Delmas PD. Glutamate receptors are expressed by bone cells and are involved in bone resorption. Bone. 22: 295-299. 1998.

166. Carlton SM, Hargett GL, and Coggeshall RE. Localization and activation of glutamate receptors in unmyelinated axons of rat glabrous skin. Neurosci Lett. 197: 25-28. 1995.

167. Kanai Y, Bhide PG, DiFiglia M, and Hediger MA. Neuronal high-affinity glutamate transport in the rat central nervous system. Neuroreport. 6: 2357-2362. 1995.

168. Kanai Y, Smith CP, and Hediger MA. A new family of neurotransmitter transporters: the high-affinity glutamate transporters. FASEB J. 8: 1450-1459. 1994.

169. Kanai Y, Trotti D, Nussberger S, and Hediger MA. The high-affinity glutamate transporter family, structure, function, and physiological relevance. In: Neurotransmitter Transporters: Structure, Function, and Regulation. MEA Reith (ed). Humana Press, Totowa, NJ. 171-213. 1997.

170. Kanai $Y$ and Hediger MA. Primary structure and functional characterization of a high-affinity glutamate transporter. Nature. 360: 467-471. 1992.

171. Pines G, Danbolt NC, Bjoras M, Zhang Y, Bendahan A, Eide L, Koepsell H, Storm-Mathisen J, Seeberg E, and Kanner BI. Cloning and expression of a rat brain Lglutamate transporter. Nature. 360: 464-467. 1992.

172. Fairman WA, Vandengerg RJ, Arriza JL, Kavanaugh MP, and Amara SG. An excitatory amino-acid transporter with properties of a ligand-gated chloride channel. Nature. 375: 599-603. 1995.

173. Schultz K and Stell WK. Immunocytochemical localization of the high-affinity glutamate transporter, EAAC1, in the retina of representative vertebrate species. Neurosci Lett. 211: 191-194. 1996.

174. Arriza JL, Eliasof S, Kavanaugh MP, and Amara SG. Excitatory amino acid transporter 5, a retinal glutamate transporter coupled to a chloride conductance. Proc Natl Acad Sci. 94: 4155-4160. 1997.

175. Brew H and Attwell D. Electrogenic glutamate uptake is a major current carrier in the membrane of axolotl retinal glial cells. Nature. 327: 707-709. 1987.

176. Schwartz EA and Tachibana M. Electrophysiology of glutamate and sodium co-transport in a glial cell of the salamander retina. J Physiol. 426: 43-80. 1990.

177. Barbour B, Brew H, and Attwell D. Electrogenic uptake of glutamate and aspartate into glial cells isolated from the salamander (Ambystoma) retina. J Physiol. 436: 169-193. 1991.

178. Barbour B, Brew H, and Attwell D. Electrogenic glutamate uptake in glial cells is activated by intracellular potassium. Nature. 335: 433-435. 1988.

179. Bouvier M, Szatkowski M, Amato A, and Attwell D. The glial cell glutamate uptake carrier countertransports $\mathrm{pH}$ changing ions. Nature. 360: 471-474. 1992.

180. Naito $\mathrm{S}$ and Ueda T. Adenosine triphosphate-dependent uptake of glutamate into Protein I-associated synaptic vesicles. J Biol Chem. 258: 696-699. 1983.

181. Tabb JS and Ueda T. Phylogenetic studies on the synaptic vesicle glutamate transporter. J Neurosci. 11: 1822-1828. 
1991.

182. Fykse EM and Fonnum F. Amino acid neurotransmission: dynamics of vesicular uptake. Neurochem Res. 21: 10531060. 1996.

183. Picaud SA, Larsson HP, Grant GB, Lecar H, and Werblin FS. Glutamate-gated chloride channel with glutamatetransporter-like properties in cone photoreceptors of the tiger salamander. J Neurophysiol. 74: 1760-1771. 1995.

184. Grant GB and Werblin FS. A glutamate-elicited chloride current with transporter-like properties in rod photoreceptors of the tiger salamander. Vis Neurosci. 13: 135-144. 1996.

185. Grant GB and Dowling JE. A glutamate-activated chloride current in cone-driven ON bipolar cells of the white perch retina. J Neurosci. 15: 3852-3862. 1995.

186. Grant GB and Dowling JE. ON bipolar cell responses in the teleost retina are generated by two distinct mechanisms. J Neurophysiol. 76: 3842-3849. 1996.

187. Roberts E and Frankel S. Gamma-aminobutyric acid in brain: its formation from glutamic acid. J Biol Chem. 187: 55-63. 1950.

188. Awapara J, Landua A, Fuerst R, and Seale B. Free gammaaminobutyric acid in brain. J Biol Chem. 187: 35-39. 1950.

189. Erlander MG and Tobin AJ. The structural and functional heterogeneity of glutamic acid decarboxylase: a review. Neurochem Res. 16: 215-226. 1991.

190. Otsuka J, Iversen LL, Hall ZW, and Kravitz EA. Release of gamma-aminobutyric acid from inhibitory nerves of lobster. Proc Natl Acad Sci USA. 56: 1110-1115. 1966.

191. Krnjevic K. Chemical nature of synaptic transmission in vertebrates. Physiol Rev. 54: 418-540. 1974.

192. Roberts E. GABA: the road to neurotransmitter status. In: Benzodiazepine/GABA Receptors and Chloride Channels: Structural and Functional Properties. RW Olsen and CJ Venter (eds). Alan R Liss, New York. 1-39. 1986.

193. Walters RJ. Excitation and adrenaline: GABA - the biopolar neurotransmitter. Cell Sci. 1: 20-22. 2004.

194. Guastella J, Nelson N, and Nelson H. Cloning and expression of a rat brain GABA transporter. Science. 249: 1303-1306. 1990.

195. Borden LA, Smith KE, Hartig PR, Branchek TA, and Weinshank RL. Molecular heterogeneity of the gammaaminobutyric acid (GABA) transport system. J Biol Chem. 267: 21098-21104. 1992.

196. Gill SS, Veinot J, Mueller R, Kavanagh M, Rousseaux CG, and Pulido OM. Toxicologic Pathology of glutamate receptors (GluRs)-an opportunity for pharmaceutical development. Part II: Inflammation and lymphoid organs. Toxicol. Pathol. 34: P29. 2006.

197. Bleich S, Romer K, Wiltfang J, and Kornhuber J. Glutamate and the glutamate receptor system: a target for drug action. Int J Geriatr Psychiatry. 18: S33-S40. 2003.

198. Chebib $M$ and Johnston GAR. The "ABC" of GABA receptors: A brief review. Clin Exper Pharmacol Physiol. 26: 937. 1999.

199. Boormann JJ. Electrophysiology of GABAA and GABAB receptor subtypes. Trends Neurosci. 11: 112-116. 1988.

200. Boormann JJ. The "ABC" of GABA receptors. Trends Pharmacol Sci. 21: 16-19. 2000.

201. Barnard EA, Darlison MG, and Seeburg P. Molecular biology of the GABAA receptor: the receptor channel superfamily. Trends Neurosci. 10: 502-509. 1987.
202. Olsen RW and Tobin AJ. Molecular biology of GABAA receptors. FASEB J. 4: 1469-1480. 1990.

203. Chen G, Trombley PQ, and van den Pol AN. GABA receptors precede glutamate receptors in hypothalamic development; differential regulation by astrocytes. J Neurophysiol. 74: 1473-1484. 1995.

204. Bertrand PP and Galligan JJ. Alfaxalone, pentobarbital and diazepam potentiate gamma-aminobutyric acid-induced depolarizations in single myenteric neurons of guinea pig intestine. J Pharmacol Exp Ther. 262: 677-682. 1992.

205. Schofield PR, Darlison MG, and Fujita N. Sequence and functional expression of the GABAA receptor shows a ligand gated receptor superfamily. Nature. 328: 221-227. 1987.

206. Macdonald RL and Twyman RE. Biophysical properties and regulation of GABAA receptor channels. Semin Neurosci. 3: 219-230. 1991.

207. Curtis DR, Duggan AW, Felix D, and Johnston GAR. GABA, bicuculline and central inhibition. Nature. 226: 1222-1224. 1970.

208. Haefely W, Kulcsar A, Mohler H, Pieri L, Polc P, and Schaffner R. Possible involvement of GABA in the central actions of benzodiazepines. In: Mechanism of Action of Benzodiazepines. E Costa and P Greengard (eds). Raven Press, New York. 131-151. 1975.

209. Haefely W. The GABA-benzodiazepine interaction fifteen years later. Neurochem Res. 15: 169-174. 1990.

210. Breier A and Paul SM. Anxiety and the benzodiazepineGABA receptor complex. In: Handbook of Anxiety. M Roth, R Noyes, and GC Burrows (eds). Elsevier, Amsterdam. 1988.

211. Guidotti A, Forchetti C, Corda M, Kondel D, Bennett C, and Costa E. Isolation, characterization and purification to homogeneity of an endogenous polypeptide with agonistic action on benzodiazepine receptors. Proc Natl Acad Sci USA. 80: 3531-3535. 1983.

212. Majewska MD, Harrison NL, Schwartz RD, Barker JL, and Paul SM. Steroid hormone metabolites are barbiturate-like modulators of the GABA receptor. Science. 232: 10041007. 1986

213. Paul SM and Purdy RH. Neuroactive steroids. FASEB J. 6: 2311-2322. 1992.

214. Squires RF, Casida JE, Richardson M, and Saederup E. $\left[{ }^{35} \mathrm{~S}\right]$ t-Butylbicyclophosphorothionate binds with high affinity to brain specific sites coupled to $\gamma$-aminobutyric acid-A and ion recognition sites. Mol Pharmacol. 23: 326336. 1983.

215. Suzdak PD, Schwartz RD, Skolnick P, and Paul SM. Ethanol stimulates g-aminobutyric acid receptor-mediated chloride transport in rat brain synaptoneurosomes. Proc Natl Acad Sci USA. 83: 4071-4075. 1986.

216. Neale JH, Bzdega $T$, and Wroblewska B. Nacetylaspartylglutamate: The most abundant peptide neurotransmitter in the mammalian central nervous system. J Neurochem. 75: 443-452. 2000.

217. Weight FF, Aguayo LG, and White G. GABA- and glutamate-gated ion channels as molecular sites of alcohol and anesthetic action. In: GABAergic Synaptic Transmission. G Biggio, A Concas and E Costa (eds). Raven Press, New York. 335-347. 1992.

218. Burt DR and Kamatchi GL. GABAA receptor subtypes: from pharmacology to molecular biology. FASEB J. 5: 
2916-2923. 1991.

219. Pritchett DB, Sontheimer H, and Borman CM. Transient expression shows ligand gating and allosteric potentiation of GABAA receptor subunits. Science. 242: 1306-1308. 1988.

220. Pritchett D, Sontheimer H, and Shivers BD. Importance of a novel GABAA receptor subunit for benzodiazepine pharmacology. Nature. 338: 582-585. 1989.

221. Pritchett DB, Lüddens H, and Seeburg P. Type I and type II GABAA benzodiazepine receptors produced in transfected cells. Science. 245: 1389-1392. 1989.

222. Lüddens H, Pritchett DB, and Köhler M. Cerebellar GABAA receptor selective for a behavioral alcohol antagonist. Nature. 346: 648-651. 1990.

223. Lüddens $H$ and Wisden W. Function and pharmacology of multiple GABAA receptor subunits. Trends Pharmacol Sci. 12: 49-51. 1991.

224. Johnston GA. GABA receptors: as complex as ABC? Clin Exp Pharmacol Physiol. 21: 521-526. 1994.

225. Andrade R, Malenka RC, and Nicoll RA. A G-protein couples serotonin and GABAB receptors to the same channels in hippocampus. Science. 234: 1261-1265. 1986.

226. Castelli MP, Ingianna A, Stefanini E, and Gess GL. Distribution of GABAB receptors mRNAs in the rat brain and peripheral tissues. Life Sci. 64: 1321-1328. 1999.

227. Lehninger AL, Nelson DL, and Cox WW. Principles of Biochemistry, $4^{\text {th }}$ ed. WH Freedman $\&$ Co., New York. 2004.

228. Borowsky B, Mezey E, and Hoffman BJ. Two glycine transporter variants with distinct localization in the CNS and peripheral tissues are encoded by a common gene. Neuron. 10: 851-863. 1993.

229. Guastella J, Brecha N, Weigmann C, Lester H, and Davidson N. Cloning, expression, and localization of a rat brain high-affinity glycine transporter. Proc Natl Acad Sci USA. 89: 7189-7193. 1992.

230. Paul SM. GABA and glycine. Publications - amino acids. Am College Neuropsychopharmacol. 2000. http:// www.acnp.org/G4/GN401000008/CH008.html (accsessed 2007/06/17)

231. Betz H. Structure and function of inhibitory glycine receptors. Q Rev Biophys. 25: 381-394. 1992.

232. Betz H. Ligand-gated ion channels in the brain: the amino acid receptor superfamily. Neuron. 5: 383-392.1990.

233. Vandenberg RJ, Handford CA, and Schofield PR. Distinct agonist- and antagonist-binding sites on the glycine receptor. Neuron. 3: 491-496. 1992.

234. Becker C-M. Disorders of the inhibitory glycine receptor: the spastic mouse. FASEB J. 4: 2767-2774. 1990.

235. Betz $\mathrm{H}$ and Becker C-M. The mammalian glycine receptor: biology and structure of a neuronal chloride channel protein. Neurochem Int. 13: 137-146. 1988.

236. Young AB and Snyder SH. Strychnine binding in rat spinal cord membranes associated with the synaptic glycine receptor: cooperativity of glycine interactions. Mol Pharmacol. 10: 790-809. 1974.

237. Danysz W and Parsons CG. Glycine and N-methyl-Daspartate receptors: Physiological significance and possible therapeutic applications. Pharmacol Rev. 50: 597-664. 1998.

238. Supplisson S and Bergman C. Control of NMDA receptor activation by a glycine transporter co-expressed in Xenopus oocytes. J Neurosci. 17: 4580-4590. 1997.

239. Nakanishi S. Metabotropic glutamate receptors: synaptic transmission, modulation, and plasticity. Neuron. 13: 10311037. 1994.

240. Narahashi T, Arakawa O, and Brunner EA. Modulation of GABA receptor-channel complex by alcohols and general anesthetics. In: GABAergic synaptic Transmission. G Biggio, A Concas and E Costa (eds). New York: Raven Press. 325-334. 1992.

241. Nakanishi S. Molecular diversity of glutamate receptors and implications for brain function. Science. 258: 597-603. 1992.

242. Takamori S, Rhee JS, Rosenmund C, and Jahn R. Identification of a vesicular glutamate transporter that defines a glutamatergic phenotype in neurons. Nature. 407: 189-194. 2000.

243. Kew JN and Kemp JA. Ionotropic and metabotropic glutamate receptor structure and pharmacology. Psychopharmacology (Berl). 179: 4-29. 2005.

244. Harrington EP, Moddel G, Najm IM, and Baraban SC. Altered glutamate receptor - transporter expression and spontaneous reizures in rats exposed to methylazoxymethanol in utero. Epilepsia. 48: 158-168. 2007.

245. Krizbai IA, Deli MA, Pestenácz A, Siklós L, Szabó CA, András I, and Joó F. Expression of glutamate receptors on cultured cerebral endothelial cells. J Neurosci Res. 54: 814 819. 1998.

246. Howe JR. How glutamate receptors are built. Neuroscientist. 5: 311-323. 1999.

247. Mayer ML and Armstrong N. Structure and function of glutamate ion channels. Ann Rev Physiol. 66: 161-181. 2003.

248. Yuzaki M. New New insights into the structure and function of glutamate receptors: the orphan receptor D2 reveals its family's secrets. Keio J Med. 52: 92-99. 2003.

249. McFeeters RL and Oswald RE. Emerging structural explanations of ionotropic glutamate receptor function. FASEB J. 18: 428-438. 2004.

250. Wisden W and Seeburg PH. Mammalian ionotropic glutamate receptors. Curr Opin Neurobiol. 3: 291-298. 1993.

251. McBain CJ and Mayer ML. N-methyl-D-aspartic acid receptor structure and function. Physiol Rev. 74: 723-760. 1994.

252. Danysz W and Parsons CG. NMDA receptor antagonists multiple modes of action on learning processes. Behav Pharmacol. 6: 619. 1995.

253. Cancela JM, Churchill GC, and Galione A. Coordination of agonist-induced $\mathrm{Ca}^{2+}$-signalling patterns by NAADP in pancreatic acinar cells. Nature. 398: 74-76. 1999.

254. Rosenmund C, Stern Bach Y, and Stevens CF. The tetrameric structure of a glutamate receptor channel. Nature. 280: 1596-1599. 1998.

255. Laube B, Kuhse J, and Betz H. Evidence for a tetrameric structure of recombinant NMDA receptors. J Neurosci. 18: 2954-2961. 1998.

256. Mansour M, Nagarajan N, Nehring RB, Clements JD, and Rosenmund C. Heteromeric AMPA receptors assemble with a preferred subunit stoichiometry and spatial arrangement. Neuron. 32: 841-853. 2001.

257. Yoneda Y, Kuramoto N, Kitayama T, and Hinoi E. 
Consolidation of transient ionotropic glutamate signals through nuclear transcription factors in the brain. Prog Neurobiol. 63: 697-719. 2001.

258. Asztely F and Gustafasson B. Ionotropic glutamate receptors: Their possible role in the expression of hippocampal synaptic plasticity. Mol Neurobiol. 12: 1-11. 1996.

259. Rao VR and Finkbeiner S. NMDA and AMPA receptors: old channels, new tricks, Trends Neurosci. 30: 284-291. 2007.

260. Keinanen K, Wisden W, Sommer B, Werner P, Herb A, Versoorn TA, Sakmann B, and Seeburg PH. A family of AMPA-selective glutamate receptors. Science. 249: 556560. 1990.

261. Verdoorn TA, Burnashev N, Monyer H, Seeburg PH, and Sakmann B. Structural determinants of ion flow through recombinant glutamate receptor channels. Science. 252: 1715-1718. 1991.

262. Ishii T, Moriyoshi K, Sugihara H, Sakurada K, Kadotani H, Yokoi M, Akazawa C, Shigemoto R, Mizuno N, Masu M, and Nakanishi S. Molecular characterization of the family of N-methyl-D-aspartate receptor subunits. J Biol Chem. 268: 2836-2843. 1993.

263. Moyner H, Sprengel R, Schoepfer R, Herb A, Higuchi M, Lorneli H, Burnashev N, Sakmann B, and Seeburg PH. Heteromeric NMDA receptors: molecular and functional distinction of subtypes. Science. 256: 1217-1221. 1992.

264. Clarke VRJ, Ballyk BA, Hoo KH, Mandelzys A, Pellizzari A, Bath CP, Thomas J, Sharpe EF, Davies CH, Ornstein PL, Schoepp DD, Kamboj RK, Collingridge GL, Lodge D, and Bleakman D. A hippocampal GluR5 kainate receptor regulating inhibitory synaptic transmission. Nature. 389: 599-603. 1997.

265. Malenka RC. Synaptic plasticity in the hippocampus: LTP and LTD. Cell. 78: 535-538. 1994.

266. Bear MF and Malenka RC. Synaptic plasticity: LTP and LTD. Curr Opin Neurobiol. 4: 389-399. 1994.

267. Edwards FA. LTP - a structural model to explain the inconsistencies. Trends Neurosci. 18: 250-255. 1995.

268. Rison RA and Stanton PK. Long-term potentiation and NMethyl-D-Aspartate receptors: foundations of memory and neurologic disease? Neurosci Biobehav Rev. 19: 533-552. 1995.

269. Baudry M. Similarities and contrasts between cerebellar LTD and hippocampal LTP. Behav Brain Sci. 19: 435. 1996.

270. Jeffery KJ. LTP and spatial learning - Where to next? Hippocampus. 7: 95-110. 1997.

271. Herron CE, Lester RAJ, Coan EJ, and Collingridge GL. Frequency-dependent involvement of NMDA receptors in the hippocampus: a novel synaptic mechanism. Nature. 322: 265-269. 1986.

272. Abraham WC and Tate WP. Metaplasticity: A new vista across the field of synaptic plasticity. Prog Neurobiol. 52: 303-323. 1997.

273. Grant SGN and Silva AJ. Targeting learning. Trends Neurosci. 17: 71-75. 1994.

274. Lisman J. The CAM kinase II hypothesis for the storage of synaptic memory. Trends Neurosci. 17: 406-412. 1994.

275. Partin KM, Patneau DK, Winters CA, Mayer ML, and Buonanno A. Selective modulation of desensitization at AMPA versus kainate receptors by cyclothiazide and
concanavalin-A. Neuron. 11: 1069-1082. 1993.

276. Benowitz LI and Routtenberg A. GAP-43: An intrinsic determinant of neuronal development and plasticity. Trends Neurosci. 20: 84-91. 1997.

277. Lan JY, Skeberdis VA, Jover T, Grooms SY, Lin Y, Araneda RC, Zheng X, Bennett MV, and Zukin RS. Protein kinase $\mathrm{C}$ modulates NMDA receptor trafficking and gating. Nat Neurosci. 4: 382-390. 2001.

278. Bayer KU, De Koninck P, Leonard AS, Hell JW, and Schulman H. Interaction with the NMDA receptor locks CaMKII in an active conformation. Nature. 411: 801-805. 2001.

279. Maren S, Tocco G, Standley S, Baudry M, and Thompson RF. Postsynaptic factors in the expression of long-term potentiation (LTP) - increased glutamate receptor binding following LTP induction in vivo. Proc Natl Acad Sci USA. 90: 9654-9658. 1993.

280. Ambros-Ingerson J and Lynch G. Channel gating kinetics and synaptic efficacy - a hypothesis for expression of longterm potentiation. Proc Natl Acad Sci USA. 90: 7903-7907. 1993.

281. Ambros-Ingerson J, Xiao P, Larson J, and Lynch G. Waveform analysis suggests that LTP alters the kinetics of synaptic receptor channels. Brain Res. 620: 237-244. 1993.

282. Benke TA, Luthi A, Isaac JTR, and Collingridge GL. Modulation of AMPA receptor unitary conductance by synaptic activity. Nature. 393: 793-797. 1998.

283. Kessler M, Arai A, Vanderliksh P, and Lynch G. Failure to detect changes in ampa receptor binding after long-term potentiation. Brain Res. 560: 337-341. 1991.

284. Che YH, Tamatani M, and Tohyama M. Changes in mRNA for post-synaptic density-95 (PSD-95) and carboxyterminal PDZ ligand of neuronal nitric oxide synthase following facial nerve transection. Brain Res Mol Brain Res. 76: 325-335. 2000.

285. Lynch MA. Mechanisms underlying induction and maintenance of long-term potentiation in the hippocampus. Bioessays. 10: 85-90. 1989.

286. Odell TJ, Hawkins RD, Kandel E R, and Arancio O. Tests of the roles of 2 diffusible substances in long-term potentiation - Evidence for nitric oxide as a possible early retrograde messenger. Proc Natl Acad Sci USA. 88: 1128511289. 1991.

287. Kato K, Clark GD, Bazan NG, and Zorumski CF. Plateletactivating factor as a potential retrograde messenger in CA1 hippocampal long-term potentiation. Nature. 367: 175-179. 1994.

288. Kato K, Uruno K, Saito K, and Kato H. Both arachidonic acid and 1-oleoyl-2-acetyl glycerol in low magnesium solution induce long-term potentiation in hippocampal CA1 neurons in vitro. Brain Res. 563: 94-100. 1991.

289. Schaechter JD and Benowitz LI. Activation of protein kinase-c by arachidonic acid selectively enhances the phosphorylation of GAP-43 in nerve terminal membranes. $J$ Neurosci. 13: 4361-4371. 1993.

290. Luo Y and Vallano ML. Arachidonic acid, but not sodium nitroprusside, stimulates presynaptic protein kinase $\mathrm{C}$ and phosphorylation of GAP-43 in rat hippocampal slices and synaptosomes. J Neurochem. 64: 1808-1818. 1995.

291. Artola A and Singer W. Long-term depression of excitatory synaptic transmission and its relationship to long-term potentiation. Trends Neurosci. 16: 480-487. 1993. 
292. Christie BR, Kerr DS, and Abraham WC. Flip side of synaptic plasticity: long-term depression mechanisms in the hippocampus. Hippocampus. 4: 127-135. 1994.

293. Cummings JA, Mulkey RM, Nicoll RA, and Malenka RC. $\mathrm{Ca}(2+)$ signaling requirements for long-term depression in the hippocampus. Neuron. 16: 825-833. 1996.

294. Derrick BE and Martinez Jr JL. Associative, bidirectional modifications at the hippocampal mossy fibre-CA3 synapse. Nature. 381: 429-434. 1996.

295. Hansel C, Artola A, and Singer W. Different threshold levels of postsynaptic $\left[\mathrm{Ca}^{2+}\right]$ (i) have to be reached to induce LTP and LTD in neocortical pyramidal cells. J Physiol Paris. 90: 317-319. 1996.

296. Kirkwood A, Rioult MG, and Bear MF. Experiencedependent modification of synaptic plasticity in visual cortex. Nature. 381: 526-528. 1996.

297. Tsumoto T, Yasuda H, Fukuda M, and Akaneya Y. Postsynaptic calcium and calcium-dependent processes in synaptic plasticity in the developing visual cortex. J Physiol - Paris. 90: 151-156. 1996.

298. Tsumoto $\mathrm{T}$ and Yasuda H. A switching role of postsynaptic calcium in the induction of long-term potentiation or longterm depression in visual cortex. Semin Neurosci. 8: $311-$ 319. 1996.

299. Christie BR, Magee JC, and Johnston D. Dendritic calcium channels and hippocampal long-term depression. Hippocampus. 6: 17-23. 1996.

300. Artola A, Hensch T, and Singer W. Calcium-induced longterm depression in the visual cortex of the rat in vitro. $\mathrm{J}$ Neurophysiol. 76: 984-994. 1996.

301. Bannerman DM, Good MA, Butcher SP, Ramsay M, and Morris RGM. Distinct components of spatial learning revealed by prior training and NMDA receptor blockade. Nature. 378: 182-186. 1995.

302. Saucier D and Cain DP. Spatial learning without NMDA receptor-dependent long-term potentiation. Nature. 378: 186-189. 1995.

303. Morris RGM. Further studies of the role of hippocampal synaptic plasticity in spatial learning: Is hippocampal LTP a mechanism for automatically recording attended experience? J Physiol - Paris. 90: 333-334. 1996.

304. Stricker C, Field AC, and Redman SJ. Changes in quantal parameters of EPSCs in rat CA1 neurones in vitro after the induction of long-term potentiation. J Physiol. 490: 443454. 1996a.

305. Stricker C, Field AC, and Redman SJ. Statistical analysis of amplitude fluctuations in EPSCs evoked in rat CA1 pyramidal neurones in vitro. J Physiol. 490: 419-441. 1996.

306. Isaac JTR, Hjelmstad GO, Nicoll RA, and Malenka RC. Long-term potentiation at single fiber inputs to hippocampal CA1 pyramidal cells. Proc Natl Acad Sci USA. 93: 8710-8715. 1996.

307. Isaac JTR, Oliet SHR, Hjelmstad GO, Nicoll RA, and Malenka RC. Expression mechanisms of long-term potentiation in the hippocampus. J Physiol - Paris. 90: 299303. 1996.

308. Manabe T and Nicoll RA. Long-term potentiation: evidence against an increase in transmitter release probability in the CA1 region of the hippocampus. Science. 265: 1888-1892. 1994.

309. Liao DZ, Hessler NA, and Malinow R. Activation of postsynaptically silent synapses during pairing-induced
LTP in CA1 region of hippocampal slice. Nature. 375: 400404. 1995.

310. Nicotera $\mathrm{P}$ and Lipton SA. Excitotoxins in neuronal apoptosis and necrosis. J Cereb Blood Flow Metab. 19: 583-591. 1999.

311. Monyer H, Sprengel R, Schoepfer R, Herb A, Higuchi M, Lomeli H, Burnashev N, Shakmann B, and Seeburg P. Heteromeric NMDA receptors: Molecular and functional distinction of subtypes. Science. 256: 1217-1221. 1992.

312. Montgomery JM, Pavlidis P, and Madison DV. Pair recordings reveal all-silent synaptic connections and the postsynaptic expression of long-term potentiation. Neuron. 29: 691-701. 2001.

313. Bibb JA, Chen J, Taylor JR, Svenningsson P, Nishi A, Snyder GL, Yan Z, Sagawa ZK, Ouimet CC, Nairn AC, Nestler EJ, and Greengard P. Effects of chronic exposure to cocaine are regulated by the neuronal protein $\mathrm{Cdk} 5$. Nature. 410: 376-380. 2001

314. Moriyoshi K, Masu M, Ishii T, Shigemoto R, Mizuno N, and Nakanishi S. Molecular cloning and characterization of the rat NMDA receptor. Nature. 354: 31-37. 1991.

315. Sharp CD, Hines I, Warren JH, Jackson IV, Jawahar A, Nanda A, Elrod JW, Long A, Chi A, Minagar A, and Alexander JS. Glutamate causes a loss in human cerebral endothelial barrier integrity through activation of NMDA receptor. Am J Physiol Heart Circ Physiol. 285: H2592_ H2598. 2003.

316. Katsuwada T, Kashiwabuchi N, Mori H, Sakimura K, Kushiya E, Araki K, Megure H, Masaki H, Kumanishi T, Arakawa M, and Mishina M. Molecular diversity of the NMDA receptor channel. Nature. 358: 36-41. 1992.

317. Chenard BL and Menniti FS. 1999. Antagonists selective for NMDA receptors containing the NR2B subunit. Curr Pharmaceut Design. 5: 381-404.

318. Mayer ML and Westbrook GL. Permeation and block of NMethyl-D-Aspartic acid receptor channels by divalent cations in mouse cultured central neurones. J Physiol. 394: 501-527. 1987.

319. Lodge D. Subtypes of glutamate receptors. Historical perspectives on their pharmacological differentiation. In: The Ionotropic Glutamate Receptors. DT Monaghan and RJ Weinhold (eds). Humana Press, New Jersey. 1-38: 1997

320. Westbrook GL and Mayer ML. Micromolar concentrations of $\mathrm{Zn}^{+2}$ antagonize NMDA and GABA responses of hippocampal neurons. Nature. 328: 640-643. 1987.

321. Ransom RW and Stec NL. Cooperative modulation of $\left[{ }^{3} \mathrm{H}\right] \mathrm{MK}-801$ binding to the N-Methyl-D-Aspartate receptor-ion channel complex by L-glutamate, glycine, and polyamines. J Neurochem. 51: 830-836. 1988.

322. Williams K, Zappia AM, Pritchett DB, Shen YM, and Molinoff PB. Sensitivity of the N-Methyl-D-Aspartate receptor to polyamines is controlled by NR2 subunits. Mol Pharmacol. 45: 803-809. 1994.

323. Johnson JW and Ascher P. Glycine potentiates the NMDA response in cultured mouse brain neurons. Nature. 325: 529-531. 1987.

324. Kleckner NW and Dingledine R. Requirement for glycine activation of NMDA-receptors expressed in Xenopus oocytes. Science. 241: 835-837. 1988.

325. Nowak L, Bregestovski P, Ascher P, Herbet A, and Prochiantz A. Magnesium gates glutamate-activated channels in mouse central neurones. Nature. 307: 462-465. 
1984.

326. Kirchoff F. NDMA receptor in glia. Neuroscientist. 13: 2837. 2007.

327. Hirai H, Kirsch J, Laube B, Betz H, and Kuhse J. The glycine binding site of the N-methyl-D-aspartate receptor subunit NR1: identification of novel determinants of coagonist potentiation in the extracellular m3-m4 loop region. Proc Natl Acad Sci. 93: 6031-6036. 1996.

328. Laube B, Hirai H, Sturgess M, Betz H, and Kuhse J. Molecular determinants of agonist discrimination by NMDA receptor subunits: Analysis of the glutamate binding site on the NR2B subunit. Neuron. 18: 493-503. 1997.

329. Salt TE. Glutamate receptor functions in sensory relay in the thalamus. Philos Trans R Soc Lond B Biol Sci. 357: 1759-1766. 2002.

330. Laurie DJ, Putzke J, Zieglgansberger W, Seeburg PH, and Tolle TR. The distribution of splice variants of the NMDAR1 subunit mRNA in adult rat brain. Mol Brain Res. 32: 94-108. 1995.

331. Sucher NJ, Awobuluyi M, Choi YB, and Lipton SA. NMDA receptors: from genes to channels. Trends Pharmacol Sci. 17: 348-355. 1996.

332. Tolle TR, Berthele A, Zieglgansberger W, Seeburg PH, and Wisden W. The differential expression of 16 NMDA and non-NMDA receptor subunits in the rat spinal cord and in periaqueductal gray. J Neurosci. 13: 5009-5028. 1993.

333. Sundstrom E, Whittemore S, Mo LL, and Seiger A. Analysis of NMDA receptors in the human spinal cord. Exp Neurol. 148: 407-413. 1997.

334. Sucher NJ, Akbarian S, Chi CL, Leclerc CL, Awobuluyi M, Deitcher DL, Wu MK, Yuan JP, Jones EG, and Lipton SA. Developmental and regional expression pattern of a novel NMDA receptor-like subunit (NMDAR-1) in the rodent brain. J Neurosci. 15: 6509-6520. 1995.

335. Kinsley CH, Madonia L, Gifford GW, Tureski K, Griffin GR, Lowry C, Williams J, Collins J, McLearie H, and Lambert KG. Motherhood improves learning and memory. Nature. 402: 137-138. 1999.

336. Matsuda K, Kamiya Y, Matsuda S, and Yuzaki M. Cloning and characterization of a novel NMDA receptor subunit NR3B: a dominant subunit that reduces calcium permeability. Brain Res Mol Brain Res. 100: 43-52. 2002.

337. Chatterton JE, Awobuluyi M, Premkumar LS, Takahashi H, Talantova M, Shin Y, Cui J, Tu S, Sevarino KA, Nakanishi N, Tong G, Lipton SA, and Zhang D. Excitatory glycine receptors containing the NR3 family of NMDA receptor subunits. Nature. 415: 793-798. 2002.

338. Chavez AE, Singer JH, and Diamond JS. Fast neurotransmitter release triggered by $\mathrm{Ca}$ influx through AMPA-type glutamate receptors. Nature. 443: 705-708. 2006.

339. Bowie D and Mayer ML. Inward rectification of both AMPA and kainate subtype glutamate receptors generated by polyamine-mediated ion channel block. Neuron. 15: 453-462. 1995.

340. Kawai $F$ and Sterling P. AMPA receptor activates a Gprotein that suppresses a cGMP-gated current. J Neurosci. 19: 2954-2959. 1999.

341. Partin KM, Fleck MW, and Mayer ML. AMPA receptor flip/flop mutants affecting deactivation, desensitization, and modulation by cyclothiazide, aniracetam, and thiocyanate. J
Neurosci. 16: 6634-6647. 1996.

342. Parsons CG, Zong XG, and Lux HD. Whole cell and single channel analysis of the kinetics of glycine-sensitive Nmethyl-D-aspartate receptor desensitization. Br J Pharmacol. 109: 213-221. 1993.

343. Sommer B, Keinanen K, Verdoorn TA, Wisden W, Burnashev N, Herb A, Kohler M, and Takagi T. Flip and Flop: a cell-specific functional switch in glutamate-operated channels of the CNS. Science. 249: 1580-1584. 1990.

344. Lerma J, Paternain AV, and Rodriguez-Moreno A. Molecular physiology of kainate receptors. Physiol Rev. 81: 971-998. 2001.

345. Vignes M, Bleakman D, Lodge D, and Collingridge GL. The synaptic activation of the GluR5 subtype of kainate receptor in area CA3 of the rat hippocampus. Neuropharmacol. 36: 1477-1481. 1997.

346. Chittajallu R, Braithwaite SP, Clarke VR, and Henley JM. Kainate receptors: subunits, synaptic localization and function. Trends Pharmacol Sci. 20: 26-35. 1999.

347. Schmitz D, Mellor J, and Nicoll RA. Presynaptic kainate receptor mediation of frequency facilitation at hippocampal mossy fiber synapses. Science. 291: 1972-1976. 2001.

348. Contractor A, Swanson G, and Heinemann SF. Kainate receptors are involved in short- and long-term plasticity at mossy fiber synapses in the hippocampus. Neuron. 29: 209216. 2001.

349. Cunha RA, Constantino MD, and Ribeiro JA. Inhibition of $\left[{ }^{3} \mathrm{H}\right]$ gamma aminobutyric acid release by kainate receptor activation in rat hippocampal synaptosomes. Eur J Pharmacol. 323: 167-172. 1997.

350. Abram SE and Olson EE. Systemic opioids do not suppress spinal sensitization after subcutaneous formalin in rats. Anesthesiology. 80: 1114-1119. 1994.

351. Wilding TJ and Huettner JE. Activation and desensitization of hippocampal kainate receptors. J Neurosci. 17: 27132721. 1997.

352. Lerma J, Morales M, Vicente MA, and Herreras O. Glutamate receptors of the kainate type and synaptic transmission. Trends Neurosci. 20: 9-12. 1997.

353. Kunishima N, Shimada Y, Tsuji Y, Sato T, Yamamoto M, Kumasaka T, Nakanishi S, Jingami H, and Morikawa K. Structural basis of glutamate recognition by a dimeric metabotropic glutamate receptor. Nature. 407: 971-977. 2000.

354. Wang JQ, Mao L, Parelkar NK, Tang Q, Liu Z, Sarwar S, and Choe ES. Glutamate-regulated behavior, transmitter release, gene expression and addictive plasticity in the striatum: roles of metabotropic glutamate receptors. Curr Neuropharmacol. 1: 1-20. 2003.

355. Couthinho V and Knoepfel T. Metabotropic glutamate receptors: electrical and chemical signaling properties. Neuroscientist. 8: 551-561. 2002.

356. Gilbertson TA, Scobey R, and Wilson M. Permeation of calcium ions through non-NMDA glutamate channels in retinal bipolar cells. Science. 251: 1613-1615. 1991.

357. Boos R, Schneider H, and Wassle H. Voltage- and transmitter-gated currents of AII amacrine cells in a slice preparation of the rat retina. J Neurosci. 13: 2874-2888. 1993.

358. Cohen ED and Miller RF. The role of NMDA and nonNMDA excitatory amino acid receptors in the functional organization of primate retinal ganglion cells. Vis Neurosci. 
11: 317-332. 1994.

359. Yu W and Miller RF. NBQX, an improved non-NMDA antagonist studied in retinal ganglion cells. Brain Res. 692: 190-194. 1995.

360. Yamada KA and Tang C-M. Benzothiadiazides inhibit rapid glutamate receptor desensitization and enhance glutamatergic synaptic currents. J Neurosci. 13: 3904-3915. 1993

361. Kessler M, Arai A, Quan A, and Lynch G. Effect of cyclothiazide on binding properties of AMPA-type glutamate receptors: lack of competition between cyclothiazide and GYKI 52466. Molec Pharmacol. 49: 123131. 1996.

362. Cartmell J and Schoepp DD. Regulation of neurotransmitter release by metabotropic glutamate receptors. J Neurochem. 75: 889-907. 2000.

363. Boulter J, Hollmann M, O'Shea-Greenfield A, Hartley M, Deneris E, Maron C, and Heinemann S. Molecular cloning and functional expression of glutamate receptor subunit genes. Science. 249: 1033-1037. 1990.

364. Hollmann M, O'Shea-Greenfield A, Rogers SW, and Heinemann S. Cloning by functional expression of a member of the glutamate receptor family. Nature. 342: 643648. 1989.

365. Bettler B, Boulter J, Hermans-Borgmeyer I, O'SheaGreenfield A, Deneris ES, Moll C, Borgmeyer U, Hollmann $\mathrm{M}$, and Heinemann S. Cloning of a novel glutamate receptor subunit, GluR5: expression in the nervous system during development. Neuron. 5: 583-595. 1990.

366. Bettler B, Egebjerg J, Sharma G, Pecht G, HermansBorgmeyer I, Moll C, Stevens CF, and Heinemann S. Cloning of a putative glutamate receptor: a low affinity kainate-binding subunit. Neuron. 8: 257-265. 1992.

367. Egebjerg J, Bettler B, Hermans-Borgmeyer I, and Heinemann S. Cloning of a cDNA for a glutamate receptor subunit activated by kainate but not AMPA. Nature. 351: 745-748. 1991

368. Gomes AR, Cunha P, Nuriya M, Faro CJ, Hugnair RL, Pires EV, Carvalho AL, and Duarte CB. Metabotropic glutamate and dopamine receptors co-regulate AMPA receptor activity through PKA in cultured chick retinal neurones: effect on GluR4 phosphorylation and surface expression. J Neurochem. 90: 673-682. 2004

369. Hu G, Duffy P, Swanson C, Ghasemzadeh MB, and Kalivas $\mathrm{PW}$. The regulation of dopamine transmission by metabotropic glutamate receptors. J. Pharmacol Exper Therapeut. 289: 412-416. 1999.

370. Cao C, Tse H, Jane D, Evans R, and Headley P. Antagonism of mGlu receptors and potentiation of EPSCs at rat spinal motoneurones in vitro. Neuropharmacol. 36: 313-318. 1997.

371. Cao C, Tse H, Jane D, Evans R, and Headley P. Metabotropic glutamate receptor antagonists, like GABA(B) antagonists, potentiate dorsal root-evoked excitatory synaptic transmission at neonatal rat spinal motoneurons in vitro. Neuroscience. 78: 243-250. 1997.

372. Dong X-W and Feldman DJL. Distinct subtypes of metabotropic glutamate receptors mediate differential actions on excitability of spinal respiratory motoneurons. J Neurosci. 19: 5173-5184. 1999.

373. Greer JJ, Smith JC, and Feldman JL. Role of excitatory amino acids in the generation and transmission of respiratory drive in neonatal rat. J Physiol. 437: 727-749. 1991.

374. Hennman E and Mendell L. Functional organization of motoneuron pool and its inputs. In: Handbook of Physiology. The Nervous System. Motor Systems. Bethesda, MD. Am Physiol Soc. sect. I, vol. II, pt. 1, chapt. 11, 423-214. 1981.

375. Lynch DR and Guttmann RP. NMDA receptor pharmacology: perspectives from molecular biology. Curr Drug Targets. 2: 215-231. 2001.

376. Hargreaves RJ, Rigby M, Smith D, and Hill RG. Lack of effect of 1-687,414 ((+)-cis-4-methyl-HA-966), an NMDA receptor antagonist acting at the glycine site, on cerebral glucose metabolism and cortical neuronal morphology. Br J Pharmacol. 110: 36-42. 1993.

377. Murata S and Kawasaki K. Common and uncommon behavioural effects of antagonists for different modulatory sites in the NMDA receptor/channel complex. Eur J Pharmacol. 239: 9-15. 1993.

378. Bristow LJ, Flatman KL, Hutson PH, Kulagowski JJ, Leeson PD, Young L, and Tricklebank MD. The atypical neuroleptic profile of the glycine/n-methyl-d-aspartate receptor antagonist, 1-701,324, in rodents. J Pharmacol Exp Ther. 277: 578-585. 1996.

379. Kretschmer BD, Kratzer U, Breithecker K, and Koch M. ACEA 1021, a glycine site antagonist with minor psychotomimetic and amnestic effects in rats. Eur J. Pharmacol. 331: 109-116. 1997.

380. Baron BM, Harrison BL, Kehne JH, Schmidt CJ, VanGiersbergen PLM, White HS, Siegel BW, Senyah Y, McCloskey TC, Fadayel GM, Taylor VL, Murawsky MK, Nyce P, and Salituro FG. Pharmacological characterization of MDL 105,519, an NMDA receptor glycine site antagonist. Eur J Pharmacol. 323: 181-192. 1997.

381. Parsons CG, Danysz W, and Quack G. Memantine is a clinically well tolerated N-methyl-D-aspartate (NMDA) receptor antagonist - a review of preclinical data. Neuropharmacol. 38: 735-767. 1999.

382. Stone TW. Kynurenines in the CNS: from endogenous obscurity to therapeutic importance. Prog. Neurobiol. 64: 185-218. 2001.

383. Hilmas C, Pereira EF, Alkondon M, Rassoulpour A, Schwarcz R, and Albuquerque EX. The brain metabolite kynurenic acid inhibits alpha7 nicotinic receptor activity and increases non-alpha7 nicotinic receptor expression: physiopathological implications. J Neurosci. 21: 7463 7473. 2001.

384. Karcz-Kubicha M, Jessa M, Nazar M, Plaznik A, Hartmann S, Parsons CG, and Danysz W. Anxiolytic activity of glycine-B antagonists and partial agonists - No relation to intrinsic activity in the patch clamp. Neuropharmacol. 36: 1355-1367. 1997.

385. Henderson G, Johnson JW, and Ascher P. Competitive antagonists and partial agonists at the glycine modulatory site of the mouse N-methyl-D-aspartate receptor. J Physiol London. 430: 189-212. 1990.

386. Kemp JA and Priestley T. Effects of (+)-HA-966 and 7chlorokynurenic acid on the kinetics of N-methyl-Dasparatate receptor agonist responses in rat cultured cortical neurons. Mol Pharmacol. 39: 666-670. 1991.

387. Lanthorn TH. D-cycloserine: agonist turned antagonist. Amino Acids. 6: 247-260. 1994. 
388. Witkin JM, Steele TD, and Sharpe LG. Effects of strychnine-insensitive glycine receptor ligands in rats discriminating dizocilpine or phencyclidine from saline. $\mathbf{J}$ Pharmacol Exp Ther. 280: 46-52. 1997.

389. Priestley T and Kemp JA. Kinetic study of the interactions between the glutamate and glycine recognition sites on the $\mathrm{N}$-methyl-D-aspartic acid receptor complex. Mol Pharmacol. 46: 1191-1196. 1994.

390. Fossom LH, Basile AS, and Skolnick P. Sustained exposure to 1-aminocyclopropanecarboxylic acid, a glycine partial agonist, alters N-methyl-D-aspartate receptor function and subunit composition. Mol Pharmacol. 48: 981-987. 1995.

391. Krueger JM, O'Connor AJ, and Kelso SR. Glycine site agonists exhibit subunit specific effects on NMDA receptors expressed in Xenopus oocytes. Soc Neurosci Abst. 23: 945. 1997.

392. Skolnick P, Marvizon JCG, Jackson BW, Monn JA, Pice $\mathrm{KC}$, and Lewin AP. Blockade of N-methyl-D-aspartate induced convulsions by 1-aminocyclopropanecarboxylates. Life Sci. 45: 1647-1656. 1989.

393. Skolnick P, Miller R, Young A, Boje K, and Trullas R.
Chronic treatment with 1-aminocyclopropanecarboxylic acid desensitizes behavioral responses to compounds acting at the N-methyl-D-aspartate receptor complex. Psychopharmacol. 107: 489-496. 1992.

394. Papp and Moryl, 1996 Cited in [Gill SS and Pulido OM. Glutamate receptors in peripheral tissues: excitatory transmission outside of the CNS. Kluwer Academic/Plenum Publishers. New York. 2005].

395. O'Connor AJ, Evalchogiannnis G, and Moskal J. Subunit specific effects of D-cycloserine on NMDA receptor receptors expressed in Xenopus oocytes. Soc. Neurosci. Abs. 22, \#604.15. 1996.

396. Sheinin A, Shavit S, and Benveniste M. Subunit specificity and mechanism of action of NMDA partial agonist Dcycloserine. Neuropharmacol. 41: 151-158. 2001.

397. Durand GM, Kovalchuk Y, and Konnerth A. Long-term potentiation and functional synapse induction in developing hippocampus. Nature. 381: 71-75. 1996.

398. Rosenmund C, Clements JD, and Westbrook GL. Nonuniform probability of glutamate release at a hippocampal synapse. Science. 262: 754-757. 1993. 